IZA DP No. 6492

Changes in China's Wage Structure

Suqin $\mathrm{Ge}$

Dennis Tao Yang

April 2012

Forschungsinstitut zur Zukunft der Arbeit Institute for the Study of Labor 


\title{
Changes in China's Wage Structure
}

\author{
Suqin Ge \\ Virginia Tech \\ Dennis Tao Yang \\ Chinese University of Hong Kong \\ and IZA
}
Discussion Paper No. 6492
April 2012

IZA

P.O. Box 7240

53072 Bonn

Germany

Phone: +49-228-3894-0

Fax: +49-228-3894-180

E-mail: iza@iza.org

\begin{abstract}
Any opinions expressed here are those of the author(s) and not those of IZA. Research published in this series may include views on policy, but the institute itself takes no institutional policy positions.

The Institute for the Study of Labor (IZA) in Bonn is a local and virtual international research center and a place of communication between science, politics and business. IZA is an independent nonprofit organization supported by Deutsche Post Foundation. The center is associated with the University of Bonn and offers a stimulating research environment through its international network, workshops and conferences, data service, project support, research visits and doctoral program. IZA engages in (i) original and internationally competitive research in all fields of labor economics, (ii) development of policy concepts, and (iii) dissemination of research results and concepts to the interested public.
\end{abstract}

IZA Discussion Papers often represent preliminary work and are circulated to encourage discussion. Citation of such a paper should account for its provisional character. A revised version may be available directly from the author. 


\section{ABSTRACT}

\section{Changes in China's Wage Structure*}

Using a national sample of Urban Household Surveys, we document several profound changes in China's wage structure during a period of rapid economic growth. Between 1992 and 2007, the average real wage increased by 202 percent, accompanied by a sharp rise in wage inequality. Decomposition analysis reveals 80 percent of this wage growth to be attributable to higher pay for basic labor, rising returns to human capital, and increases in the state-sector wage premium. Employing an aggregate production function framework, we account for the sources of wage growth and wage inequality in the face of globalization and economic transition. We find capital accumulation, skill-biased technological change, and export expansion to be the major forces behind the evolving wage structure in China.

JEL Classification: J31, E24, O40

Keywords: $\quad$ wage growth, wage premium, capital accumulation, trade expansion, technological change, China

Corresponding author:

Dennis Tao Yang

Department of Economics

Chinese University of Hong Kong

Shatin, N.T.

Hong Kong

E-mail: deyang@cuhk.edu.hk

\footnotetext{
* We would like to thank Peter Debaere, Avraham Ebenstein, Belton Fleisher, Gordon Hanson, Han Hong, Mark Rosenzweig, Wing Suen, Shing-Yi Wang, Frank Warnock, Bruce Weinburg, and seminar and conference participants from various institutions for their valuable comments and suggestions. We are also grateful to Jessie Pang for her excellent research assistance. In addition, the authors would like to acknowledge the financial support of the Research Grants Council of the Hong Kong Special Administrative Region, China (Project No. 457310) and CCK Foundation for Scholarly Exchange. All errors are our own. An earlier version of this paper was entitled "Accounting for Rising Wages in China."
} 


\section{Introduction}

Over the past two decades, China's gross domestic product (GDP) has grown by more than 10 percent per year, turning the country into the world's fastest growing economy. ${ }^{1}$ Against this backdrop of rapid economic growth, this paper documents the profound changes in China's wage structure using the unique national sample of Urban Household Surveys (UHS). We track the rising wage of unskilled workers and examine changes in wage premiums by education, gender, ownership type, industry, and geographic region. Further investigations are conducted to identify the sources of wage growth and wage inequality. Episodes of extraordinary economic growth also occurred in other East Asian economies, such as Japan in the 1950s and 1960s and South Korea in the 1970s and 1980s. ${ }^{2}$ However, little is known about the structural changes in wages that took place during these episodes. The current study is intended to fill this void in the literature by illuminating the wage trends and mechanisms of wage determination during China's rapid development.

Between 1992 and 2007, the average real wage in urban China increased by 202 percent. $^{3}$ The wage gains in this period consist not only of growth in the base wage for unskilled workers but also in wage premiums. Although wages for workers with a middle school education grew by an extraordinary 135 percent, those for college-educated workers saw an even more phenomenal rise, increasing more than 240 percent, thus resulting in a sharp rise in the skill premium (see Table 1). The wage premium for state employees also achieved remarkable gains. The 260-percent wage growth enjoyed by these employees far surpassed that of their counterparts in collective, private, and foreign firms. Another significant wage trend during the 1992-2007 period was a significant increase in the gender earnings gap. Although some of our analyses provide novel observations on the Chinese labor market, others corroborate the results of existing studies covering select regions with a consistent national sample of workers over an extended period. ${ }^{4}$ An important goal of this paper is

\footnotetext{
${ }^{1}$ See Song, Storesletten and Zilibotti (2011) for a recent study on the sources and mechanisms of China's phenomenal economic growth over the past two decades.

${ }^{2}$ In the 1980s, real per capita income grew by 64 percent in Hong Kong, 122 percent in the Republic of Korea, 78 percent in Singapore, and 88 percent in Taiwan (Fields, 1994). Real wages in Korea nearly tripled in the 1971-1986 period (Kim and Topel, 1995), and they also grew rapidly in postwar Japan, climbing by 180 percent between 1952 and 1965.

${ }^{3}$ Unless otherwise noted, all wage and employment statistics cited in this paper are based on data from the national UHS sample collected by China's National Bureau of Statistics (NBS), a dataset not previously available to researchers. Wages are defined as annual labor earnings, and we employ the two terms interchangeably in this paper. Section 3 and the appendix provide detailed descriptions of the data.

${ }^{4}$ For instance, our finding of a continued wage hike for unskilled labor challenges the popular view that the Lewis turning point has only just arrived in China, a view that posits a recent, sudden increase in the basic wage for unskilled labor after a long period of wage stagnation. The rising wage premium for the state sector and the long-term persistent increase in the gender earnings gap also lack documentation in the existing literature.
} 
to bring these findings to the fore and explore the forces of wage determination in a unified framework.

Our subsequent decomposition analysis identifies three main sources of wage growth in China: (a) a higher wage for basic labor, (b) increasing returns to human capital, and (c) a rise in the state-sector wage premium. Together, these three factors account for 80 percent of the wage growth observed during the 16-year period under study. Other factors - such as the rise in labor quality, the gender composition of the labor force, and labor reallocations across regions and industries - make only minor contributions.

To account for the driving forces behind China's wage growth, we develop a static twosector model employing an aggregate production function framework. The model specifies skilled and unskilled labor as imperfect substitutes employed in the state or private sector, and posits that skills complement capital. Incorporated into the model are key features of the Chinese economy, including capital accumulation, skill-biased technological change (SBTC) through research and development $(\mathrm{R} \& \mathrm{D})$ expenditures and foreign direct investment (FDI), economic restructuring that has lessened the protection of state employment, and changes in the relative skill supply. Taking these potential driving forces of wage trends as given, we apply market equilibrium conditions to solve the model for the base wage, schooling premium, and state-sector wage premium. Supplementing the UHS data with our own collection of aggregate data across ownership sectors, we estimate the model parameters structurally. Subsequently, through counterfactual experiments, we find capital accumulation and SBTC to be the key contributors to the rise in the base wage and skill premium. The restructuring of the state sector has also played an essential role in raising the state-sector wage premium. This empirical framework also allows us to assess the labor market consequences of such major events as China's accession to the World Trade Organization (WTO). We find that the resulting expansion of exports has raised the base wage, although the ongoing flow of rural labor into cities has partly mitigated the upward wage pressure. Overall, our estimated model accounts well for the evolving wage structure in China.

There is a vast body of literature on wage structure changes in both developed and developing countries. ${ }^{5}$ This research has focused largely on earnings inequality because, relative to the substantial and widespread earnings divergence seen within many economies in recent decades, wage growth has been modest. However, as a rise in the wage level is a distinctive feature of the labor market in a fast-growing economy, we examine the determinants of wage growth and wage inequality jointly, an emphasis that builds upon

\footnotetext{
${ }^{5}$ See Katz and Autor (1999) for a comprehensive review of the literature on the wage structure in advanced economies, and Goldberg and Pavcnik (2007) for a discussion of income inequality in developing countries with a focus on the effects of globalization.
} 
two aspects of the existing literature. First, we closely follow the supply-demand-institution framework (e.g., Bound and Johnson, 1992; Katz and Murphy, 1992; Juhn, Murphy and Pierce, 1993; Freeman and Katz, 1994; DiNardo, Fortin and Lemieux, 1996; Autor, Katz and Krueger, 1998) and apply the key wage determinants posited in the literature to investigate China's changing labor market. Second, the specification of aggregate production functions with capital-skill complementarity highlighted by Fallon and Layard (1975), Goldin and Katz (1998), and Krussell et al. (2000) is central to both our model construction and empirical estimation. $^{6}$

This paper also contributes to the burgeoning literature on labor market developments in China. Existing research in this area typically focuses on such topics as wage differentials between the state and non-state sectors, the consequences of enterprise restructuring, wage discrimination and inequality, and returns to education. ${ }^{7}$ Instead of investigating one aspect of the labor market in certain regions during specific survey periods, we conduct a comprehensive assessment of the nationwide evolution of the wage structure over an extended period. Our coherent framework allows us to demonstrate that the changes in several components of the wage structure are inter-related, that is, they are influenced by a common set of forces arising from globalization, economic transition, and rapid growth. Our empirical findings reveal a multifaceted process of economic development through the lens of the labor market.

The remainder of the paper proceeds as follows. Section 2 outlines the labor market

conditions in China, describes the UHS data, documents the major trends in wages and employment, and decomposes the sources of wage growth. Section 3 develops and estimates a two-sector labor market model to investigate the driving forces behind rising wages and widening wage inequality in China, and Section 4 concludes the paper.

\section{Wage and Employment Structural Changes}

\subsection{Labor Market Conditions}

China's economic reforms began in 1978. In 1992, after a period of economic and political instability, then Chinese leader Deng Xiaoping took his famous "southern tour" during which he reasserted the continuity of these reforms. Five years later, the Chinese government's

\footnotetext{
${ }^{6}$ We also draw on useful features from other studies that estimate lifecycle decisions in a dynamic general equilibrium framework and account for the effects of demand and supply factors on wage inequality (e.g., Heckman et al., 1998; Lee and Wolpin, 2010).

${ }^{7}$ Studies covering these topics include Zhao (2002), Giles, Park and Zhang (2005), Gustafsson and Li (2000), Knight and Song (2003), Meng and Kidd (1997), and Zhang et al. (2005).
} 
announcement of a massive privatization program involving the sale, merger, or closure of the vast majority of inefficient state-owned enterprises (SOEs) took the country a step closer to a fully fledged market economy. The resulting economic restructuring led to a precipitous decline in state employment and concurrent expansion of the private sector. China's accession to the WTO in 2001 was yet another milestone in the country's integration into the world economy and dramatically expanded the market for Chinese exports. From 1992 to 2007, China's GDP grew by 10.7 percent per year. Against this backdrop of rapid economic growth, labor market conditions in urban China experienced a number of profound changes.

The demand for labor is closely related to investments in physical capital. In the 19922007 period, total investment in fixed assets jumped from 0.81 to 13.73 trillion yuan (NBS, 2008). ${ }^{8}$ As a result, the capital-output ratio in China increased from 1.36 to 1.72 over this 16-year period (Bai, Hsieh and Qian, 2006). Capital accumulation raises the marginal product of labor. If production technology exhibits capital-skill complementarity, then a rise in capital stock should raise the marginal product of skilled labor more than it raises that of unskilled labor, thus leading to a greater disparity in relative wages.

Technological change is another driving force behind China's evolving wage structure. Advances in technology can be achieved by domestic investments in $R \& D$ and by learning new technology from industrialized economies. In China, total R\&D expenditures rocketed from 22.4 to 178.4 billion yuan between 1992 and 2007. China also became the second largest recipient of FDI in this period, with utilized investment reaching US $\$ 74.8$ billion in 2007, up from US $\$ 11.0$ billion in 1992. FDI is likely to be an important channel for the diffusion of ideas and technologies (e.g., Barrell and Pain, 1997), and thus a source of demand for skilled labor (Feenstra and Hanson, 1997). The upgrading of technologies can be particularly beneficial to highly skilled workers because SBTC has been found to boost their wages relative to their unskilled counterparts.

As noted, China's accession to the WTO has expanded international demand for Chinese goods, thus allowing the country to capitalize fully on its abundant supply of labor. From 1992 to 2000, exports' share of GDP fluctuated between 15 to 21 percent, but this ratio rose rapidly thereafter, reaching more than 36 percent in 2007. In 2001, China's export growth began to outpace its import growth by a large margin, resulting in a huge trade surplus of close to 8 percent of GDP by the end of the study period (NBS, 2008). This dramatic expansion in trade has turned China into the world's largest exporter of manufactured goods. The booming manufacturing sector has increased demand for workers with basic skills, creating upward pressure on the base wage, and, in turn, inducing the inflow of rural migrants into

\footnotetext{
${ }^{8}$ The lion's share of fixed assets was invested in urban China, accounting for 0.61 and 11.75 trillion yuan, respectively, in the two years.
} 
cities.

On the supply side, college enrollment and the number of college graduates has continued to increase since the inception of reforms. Although the rise held steady throughout the 1980s and much of the 1990s, a new policy of nationwide college expansion took effect in 1999. In that year alone, college admissions surged by nearly 50 percent to reach 1.60 million. As a result of this initiative, the number of college graduates jumped more than five-fold in less than a decade: from 0.85 million in 1999 to 4.48 million in 2007 (NBS, 2008). At the same time, urban China experienced an influx of rural migrants. Although China's centrally planned economy greatly restricted labor mobility, rural-urban migration grew rapidly following the series of deregulation measures that began in the late 1980s. Analysis of the 2005 population census reveals that about three-quarters of rural migrants had an educational attainment of middle school or below (middle school hereafter) in that year. Overall, the educational attainments of the urban workforce increased over the study period.

Along with changes in demand and supply, labor market institutions were likewise transformed. Under the central planning regime, government labor bureaus assigned workers to state and collective enterprises, where they enjoyed secure employment, known as the "iron rice bowl," and wages were determined by a grade system. Labor market reforms made progress toward a market-oriented system with flexible wage determination, employment contracts, and increased job mobility. Since the mid-1980s, urban wage reforms have made it possible for wages to reflect firm profitability and worker productivity. By the early 1990s, skilled workers were already searching for better-paid jobs in the non-state sector, whereas the disguised unemployment of low-skilled labor prevailed in SOEs because of the government's political objective to reduce unemployment and ensure social stability (e.g., Dong and Putterman, 2003). In 1997, however, the mounting losses of SOEs prompted the Chinese government to launch a drastic state-sector restructuring program known as xiagang (or "leaving the current position"). The objective was to shut down loss-making SOEs, establish modern forms of corporate governance, and de-link the provision of social services from individual employers. These aggressive reforms led to the layoffs of 40 million workers from the public sector between 1996 and 2002 (e.g., Giles, Park and Zhang, 2005), effectively ending protectionism in state employment. These profound changes in labor market conditions provide a unique opportunity to investigate the major forces behind the determination of the wage structure amid rapid economic growth. 


\section{$2.2 \quad$ The Data}

The primary data source for this paper is the 16 consecutive years of UHSs conducted by the NBS for the 1992-2007 period. This repeated cross-sectional dataset records the basic socioeconomic conditions of Chinese urban households, including detailed information on employment, earnings and expenditures as well as the demographic characteristics of household members. The survey design of the UHS is similar to that of the Current Population Surveys (CPS) in the U.S. and the information on employment and earnings is comparable to that of the March CPS, which is widely used in the study of the U.S. wage and employment structure. The UHS is the only nationally representative household dataset in China that encompasses all provinces and contains yearly information dating back to the early 1990s. This is the first study to employ the national UHS sample to analyze the evolution of the Chinese labor market over an extended period of time. ${ }^{9}$

The wage measure that we employ throughout the paper is the average annual wage of representative workers with a strong labor market attachment. Wage income consists of the basic wage, bonuses, subsidies, and other labor-related income from a regular job. We deflate annual wages to 2007 yuan by province-specific urban consumption price indices (CPI). ${ }^{10}$ Ideally, we would focus on the weekly or hourly wages of full-time workers for consistency with previous studies of the wage structure (e.g., Bound and Johnson, 1992; Katz and Murphy, 1992; Juhn, Murphy and Pierce, 1993). However, information on working hours is unavailable in the UHS for most of the survey years. Between 2002 and 2006, when working hours were reported for the month prior to the survey, the average number of monthly hours in the sample fluctuated within the narrow range of 180 to 184, thus suggesting that actual working hours held steady over time. Hence, there appear to be limited measurement errors in the annual wage measure due to possible changes in the intensity of labor supply. Our sample for analysis includes all female workers aged 16-55 and male workers aged 16-60 as 55 and 60 are the official retirement ages in China for women and men, respectively. Moreover, consistent with standard studies of the wage structure, we exclude from our sample business employers, self-employed individuals, farm workers, retirees, students, those re-employed after retirement, and workers whose wages are less than one half the minimum wage. The resultant sample contains 655,372 individuals in the 16 years of repeated cross-sectional data. In the 1992-2001 period, the annual sample size ranges from 22,418 to 30,306 workers. After

\footnotetext{
${ }^{9}$ The NBS has various regulations restricting data access. The Chinese University of Hong Kong enjoys a long-standing collaborative relationship with the NBS and was able to acquire UHS data for much of the 1990s. We were able to expand this data usage to all provinces and up to 2007 for this project.

${ }^{10} \mathrm{CPI}$ have slightly higher values than the GDP deflator. When we use the province-specific GDP deflator to deflate wage income, the real wage growth rate between 1992 and 2007 increases by around 15 percent, but the patterns of the wage structure change remain the same.
} 
2002 , it increases to more than 62,206 per year.

The UHS adopts a framework of the stratified random sampling of urban households, and this survey method has remained consistent over the years. However, we note two data caveats that are addressed carefully in subsequent analyses. First, prior to 2002, the UHS sampled only households with official urban household registration status (hukou), thus excluding rural migrants without legal registration, who are considered the "floating population" in China (e.g., Chan and Zhang, 1999). Although UHS coverage was expanded in 2002 to include all households with a residential address in an urban area, regardless of registration status, rural-to-urban migrant workers remain under-represented because many of them live on the periphery of cities, in employer-provided dormitories, or in their workplaces such as construction sites. In Section 3, in which we perform empirical estimation of wage determination, we impute the size of the rural-to-urban migrant workforce and treat these individuals as part of the aggregate urban labor supply. Second, UHS data are known to over-represent workers from state and collective enterprises whose survey response rates are systematically higher than those of workers employed in private sector firms. We deploy an elaborate re-sampling scheme that adjusts the sample distribution of workers by ownership type to the more reliable figures of national worker distributions based on firm-level surveys. Appendix A provides detailed descriptions of the UHS sample restrictions, data adjustments, and variable definitions.

\subsection{Trends in Wages and Employment}

Table 1 describes the structural changes in China's wages and employment between the first and last years of the study period, 1992 and 2007. The most prominent change is that the average real wage increased by 201.9 percent, from 6,193 to 18,695 yuan, over this 16year period. Other striking labor market trends also emerge from the table. We first place emphasis on documenting employment changes, followed by more elaborate analysis of the evolving wage structure.

The top parts of the table show changes in the real wage and employment composition by education level and sex. From 1992 to 2007, the employment share made up of college and university workers (college graduates hereafter) rose from 16.7 to 33.6 percent, more than doubling in 16 years, whereas that of workers with a middle school education declined by a similar percentage. This upsurge in educational attainment reflects the policy effects of expanding college enrollment in the late 1990s. The popularity of obtaining collegeequivalence diplomas among adults also contributed to the rise in worker quality. ${ }^{11}$ However,

\footnotetext{
${ }^{11}$ Our classification of "college workers" comprises workers with any post-secondary education. In the UHS data, we are unable to separate college graduates from those who merely attended college or to differentiate
} 
despite the large increase in the supply of college graduates, their real wage climbed 240 percent over this period, growing at a much higher rate than that of high school and middle school graduates.

Parallel to this rise in educational attainment, women's employment share declined from 49.8 percent in 1992 to 46.1 percent in 2007, with women gradually losing their historical legacy of "holding half of the sky" from the central planning era. Indeed, the rate of labor market participation by women between the prime ages of 16 and 55 dropped by 11 percentage points during the 16-year period under study, declining to 81.2 percent by 2007. Although the real wage soared for both men and women in this period, the growth of men's wage outpaced that of women by 30.6 percentage points, thus widening the initial male-female earnings gap in the early 1990s.

The middle section of Table 1 shows that the wages of state-sector employees grew at a much faster rate (259.8 percent) than those employed in collective-individual-private enterprises (CIP; 178.2 percent) and joint-venture, stockholding, and foreign firms (JSF; 99.2 percent). Coinciding with this steep upward trend in earnings, the employment share of the state sector dropped precipitously from 69.7 percent in 1992 to 32.6 percent in 2007, as a result of ongoing privatization and state-sector restructuring since the late 1990s. The mass exodus of SOE workers was largely absorbed by the growing non-state sectors. In 1992, JSF firms employed only 1.8 percent of the urban workforce, whereas it employed 23.7 percent in 2007. Likewise, the CIP share of this workforce grew over the period from 28.5 to 43.7 percent, with these firms replacing state firms as the largest employer of urban Chinese workers in recent years.

The bottom portions of the table present wage growth and employment distribution by industry and region. Industries are reported in three broad categories: manufacturing, basic services, and advanced services. Although wages grew significantly in all industries, basic services saw the slowest growth while experiencing rapid expansion in employment numbers. Wage growth in both the manufacturing sector, which contributed more than 90 percent of China's total exports, and advanced service sector, which employed the most educated labor force, was above the national average. With regard to location, the eastern, coastal region experienced the fastest wage growth during the 16-year period despite having the highest level of initial income. It appears that the large labor inflows into the region helped maintain its wage growth not far over the national average.

individuals who have acquired formal education in a regular college/university from those who have completed college-equivalent diplomas by attending informal night classes or training programs. According to China Health and Nutrition Surveys (CHNS), 24 percent of the urban labor force graduated and received a diploma from either a regular three-year specialized college or four-year university in 2006, thus indicating that a significant number of the college workers we classify as such never graduated from formal colleges. 


\subsection{Changes in Conditional Mean Wages}

The wage trends reported in the previous section, which are categorized by one worker characteristic at a time, do not control for changes in wage levels arising from shifts in the educational, gender, firm ownership, industry, or regional composition of the labor force. A more informative documentation of the wage structure would show relative wage changes over time, holding the distribution of worker attributes fixed. Thus, we specify the following regression function.

$$
\begin{aligned}
\ln w_{i}^{t}= & \sum_{k} \beta_{k}^{t} S_{i k}^{t}+\beta_{1}^{t} X_{i}^{t}+\beta_{2}^{t} X_{i}^{t^{2}}+\beta_{g}^{t} G_{i}^{t}+ \\
& \sum_{l} \beta_{l}^{t} O_{i l}^{t}+\sum_{m} \beta_{m}^{t} I_{i m}^{t}+\sum_{n} \beta_{n}^{t} R_{i n}^{t}+\varepsilon_{i}^{t},
\end{aligned}
$$

where $S_{i k}^{t}$ are dummy variables for schooling levels with $k \in\{$ midsch, highsch, col $\}$ corresponding to middle school, high school and college graduates; $X_{i}^{t}$ and $X_{i}^{t^{2}}$ are potential experience, computed as min[(age - years of schooling - 6), (age - 16)], and experience squared, respectively; and $G_{i}^{t}$ is a dummy variable for male. $O_{i l}^{t}$ are dummy variables for ownership, where $l \in\{$ state, $J S F\}$, leaving the CIP sector as the reference group. Similarly, $I_{i m}^{t}$ are dummy variables for industry, where $m \in\{$ manu, advserv $\}$ corresponding to the manufacturing and advanced services sectors, leaving basic services as the reference group. $R_{i n}^{t}$ are dummy variables for regions, with $n \in\{$ central, west, east $\}$ and the northeast left as the reference region.

In studies of wage structural change, demographic breakdowns of the data are typically based on sex, education, and experience to control for demographic changes. In China, because of the institutional setting and economic transition, there are large variations in wages by ownership type, industry, and region. These variations are essential to understanding the wage structural change, and we therefore include them as an additional classification to compute the conditional mean wages. ${ }^{12}$

Equation (1) provides conditional mean estimates for the base wage and various wage premiums. In this study, we define the base wage as the log real annual wage of the basic reference group, which refers to female workers with a middle school education and no experience working in a CIP firm in the basic service sector in the low-income northeastern region. Hence, the parameter $\beta_{\text {midsch }}$ provides an estimate for the base wage. Other parameters in

\footnotetext{
${ }^{12}$ We could potentially introduce paired interaction terms between the worker characteristics and sector affiliations in Equation (1), but the sample size would then become a constraint. Dividing workers into 216 groups by sex, schooling level, ownership type, industry, and region leaves many cells empty, and close to 40 percent of them have fewer than 30 observations for the years before 2002. When paired interactions are allowed, more than 80 percent of the regression coefficients are statistically insignificant.
} 
the equation correspond to log wage premiums for high school and college graduates, being male, working in the state or JSF sectors, employment in the manufacturing or advanced services, and working in the wealthier central, western or eastern regions. These wage premiums are computed with the control for experience profiles. We run this conditional mean regression using the UHS cross-sectional data for each of the 16 consecutive years under study.

Figure 1 illustrates the major changes in China's wage structure from 1992 to 2007. Panel A plots the estimated mean log real base wage for each of the 16 years, whereas Panels B$\mathrm{F}$ provide estimates of the wage premiums measured by the log wage differentials between specific worker groups and their respective reference groups. Panel B, for example, presents the log wage differentials between college and middle school graduates (the reference group) and between high school and middle school graduates, holding constant the distribution of the labor force by sex, ownership, industry, and region. Several striking wage change patterns can be observed, and are summarized in the following.

1. The base wage of raw labor increased persistently and rapidly between 1992 and 2007 (Panel A). Significant wage increases occurred in the 1990s, with the log base wage rising from 7.608 in 1992 to 7.822 in 1998. Over the next 10 years, beginning with China's anticipation of WTO entry, the growth of the base wage accelerated. The log base wage climbed to 8.496 in 2007, an increase of 67.4 percent in a decade. This accelerated wage growth points to a potential link between China's dramatic trade expansion and the wage growth for unskilled workers, who are heavily recruited by export-oriented manufacturing firms. The continued wage growth for the unskilled labor force after 1992 appears to reject the notion that the Lewis turning point has arrived in China. ${ }^{13}$

2. The schooling premium, particularly the college wage premium, rose sharply (Panel $B)$. The log wage differential between college and middle school graduates doubled during the 16-year period examined here, rising from 0.25 in 1992 to 0.505 in 2007. The increase in the college wage premium occurred primarily before 2004 and, since then, has plateaued out. The high school wage premium also experienced steady increases in the early part of the period, but has remained stable since 2000. Increasing returns to education is a prominent feature of the Chinese labor market during economic transition. In fact, using the UHS data the estimated rate of return to education in 1992 was just over 40 percent of the U.S. level using CPS data (4.2 percent versus 9.7 percent), based on Mincer earnings regression with

\footnotetext{
${ }^{13}$ The classical two-sector Lewis model predicts wage stagnation when a developing country has a pool of surplus rural labor and wage rises when redundant labor is depleted. As Ge and Yang (2011) describes, the media and several empirical studies based on surveys of rural migrants posited the arrival of the Lewis turning point in China in 2003-04 or 2007-08, when wages began to grow faster than in earlier periods. These claims appear to be inconsistent with the national data presented here.
} 
controls for schooling, potential experience, and sex. By 2004, returns to education in China had fully converged with the U.S. level (11.0 percent versus. 11.1 percent) and remained comparable thereafter.

3. The wage of men relative to women increased during the study period (Panel C). Although the wages of both men and women saw substantial increases, their log wage differential increased from 0.11 in 1992 to 0.253 in 2007, a level comparable to the U.S. gender earnings gap in recent years (e.g., Mulligan and Rubinstein, 2008). The data show a steady increase in the Chinese male-female earnings gap in the 1992-1998 period, with the disparity rapidly accelerating since the late 1990s, a period that coincides with the mass layoffs that took place during the restructuring of the state sector.

4. The wage of the state sector rose relative to that of the CIP and JSF sectors (Panel $D)$. In the 1992-1998 period, the average wage of the JSF sector was about 40 percent and 60 percent higher than that of the state and CIP sectors, respectively. During this period, many better educated SOE workers began to actively search for new jobs in the non-state sector, a phenomenon known as "jumping into the sea." However, in the interests of social stability, SOEs were forbidden from laying off redundant workers, who were usually less educated and had less adaptive ability to switch jobs. The SOE restructuring that took place in the late 1990s had dramatic effects on employment and wages. Coinciding with the aforementioned sharp decline in state employment, the wage level of this sector registered impressive gains, eventually surpassing that of the JSF sector in 2004. A new phrase - "coming back to shore" - has been coined to describe the phenomenon of Chinese professionals working in the non-state sector being lured to the state sector through attractive incentives.

5. Wage inequality across basic services, manufacturing and advanced services has widened over time (Panel E). Wages across industries remained clustered in the early 1990s, after which the average wage for the skill-intensive advanced service sector surpassed that of laborintensive industries in the manufacturing and basic service sectors. By 2007, the average wage in the advanced service sector was about 15.1 percentage points higher than that in the basic service sector. Manufacturing wages declined relative to those of basic services throughout the 1990s, but this trend was reversed beginning in 2001 after China's WTO entry. The log wage differential between the tradable manufacturing sector and the non-tradable basic service sector increased by 0.147 during the 2001-2007 period.

6. The eastern regions in the coastal provinces of China maintained high wage premiums relative to other regions from 1992 to 2007 (Panel F). The wage level of the eastern region was about 30 to 40 percent higher than that of the other three regions, whose wage levels remained rather closely clustered throughout the period. Thanks in part to high wages, the eastern region has attracted a significant inflow of labor, raising its employment share by 
12.1 percentage points according to the UHS data.

The rises in the base wage and wage premiums, along with systematic changes in employment distributions, such as the increase in the proportion of workers with a college education, the decline in female labor force participation, and large labor flows to regions with high earnings, appear to be the major sources of wage growth in China. Assessing the relative contributions of these factors to rising wages is the task to which we now turn.

\subsection{Decomposition of Wage Growth}

We deploy a decomposition framework that employs the aforementioned conditional mean wages. The earnings function posits that the average wage for a working sample reflects workers' characteristics and the labor market prices of individual characteristics. Consequently, changes in the wage level over time result from two components: changes in the distribution of individual characteristics and changes in the wage premiums for different worker characteristics. Consider a wage equation in the following semi-log functional form.

$$
\ln w_{i}^{t}=\sum_{j} \beta_{j}^{t} X_{i j}^{t}+\varepsilon_{i}^{t}
$$

where $w_{i}^{t}$ is the annual wage for individual $i$ in year $t, X_{i j}^{t}$ is the individual's $j$ th characteristic (e.g., educational attainment or ownership category), $\beta_{j}^{t}$ is the market price for the $j$ th characteristic, and $\varepsilon_{i}^{t}$ represents a random error.

For wage growth from an initial year $\tau_{0}$ to an ending year $\tau$, the difference in the $\log$ wage over the two years can be written as

$$
\overline{\ln w^{\tau}}-\overline{\ln w^{\tau_{0}}}=\sum_{j} \widehat{\beta}_{j}^{\tau} \bar{X}_{j}^{\tau}-\sum_{j} \widehat{\beta}_{j}^{\tau_{0}} \bar{X}_{j}^{\tau_{0}}
$$

where $\overline{\ln w^{\tau_{0}}}$ and $\overline{\ln w^{\tau}}$ are the average log wages for years $\tau_{0}$ and $\tau$, respectively. $\left\{\bar{X}_{j}^{\tau_{0}}, \bar{X}_{j}^{\tau}\right\}$ are the mean values of the $j$ th regressor, and $\left\{\widehat{\beta}_{j}^{\tau_{0}}, \widehat{\beta}_{j}^{\tau}\right\}$ are the estimated wage premiums for the corresponding worker characteristics. Rearranging equation (3) gives us

$$
\overline{\ln w^{\tau}}-\overline{\ln w^{\tau_{0}}}=\sum_{j}\left[\alpha_{j} \widehat{\beta}_{j}^{\tau}+\left(1-\alpha_{j}\right) \widehat{\beta}_{j}^{\tau_{0}}\right]\left(\bar{X}_{j}^{\tau}-\bar{X}_{j}^{\tau_{0}}\right)+\sum_{j}\left[\alpha_{j} \bar{X}_{j}^{\tau_{0}}+\left(1-\alpha_{j}\right) \bar{X}_{j}^{\tau}\right]\left(\widehat{\beta}_{j}^{\tau}-\widehat{\beta}_{j}^{\tau_{0}}\right)
$$

where $\alpha_{j}$ s are weights with $0 \leq \alpha_{j} \leq 1$. This equation decomposes the change in the average of the log wage between the two years into two components. The first term on the right-hand side of equation (4) represents the portion of the log wage change that is due to changes in 
worker characteristics $(\bar{X})$, and the second is that due to changes in returns to characteristics $(\beta)$ or changes in the wage structure. Using equation (1), we can obtain $\beta s$ for the individual years, as shown in Figure 1. Then, by combining them with the sample values of $\bar{X}$, we can decompose the change in the log wage over two specific years into the various components of wage change.

Table 2 presents the decomposition results of wage growth from 1992 to 2007. During this period, the average real wage jumped 201.9 percent, corresponding to a 0.989 increase in the log wage differential. Setting the distribution of individual characteristics to the initial level, i.e., $\alpha_{j}=1$, the rise in the base wage alone accounts for 37.58 percent of total wage growth. Among the other sources of wage growth, 55.96 percent is attributable to changes in factor returns and sector premiums, and 6.46 percent is attributable to improvements in worker characteristics and reallocations to highly paid sectors. In the first category of changing factor returns and sector premiums, the rise in human capital returns (35.56 percent) and in the ownership premium ( 7 percent, of which 7.8 percent arises from an increase in the statesector wage premium and -0.8 percent comes from a decline in the JSF wage premium), are the two major components. Increases in the base wage of unskilled labor, returns to human capital, and state-sector wage premiums constitute the three largest contributors, together accounting for 80 percent of the observed wage growth between 1992 and 2007. ${ }^{14}$ Such factors as the rise in labor quality, labor reallocation across ownership type and industry, labor mobility across regions, and changes in wage premiums across industry and region only make relatively minor contributions to the documented wage growth.

\section{Accounting for Wage Growth and Wage Inequality}

Drawing on the foregoing decomposition results, in this section we investigate the driving forces behind the three major components of wage growth, namely, the rising base wage, increasing returns to education, and the higher wage premium for the state sector. ${ }^{15}$ Given the importance of capital accumulation to enhancing labor productivity, and thus to wage determination, we adopt an aggregate production function that employs three factor inputs: capital, skilled labor, and unskilled labor. We follow Krusell et al. (2000) in allowing for capital-skill complementarity, and we expand the existing model: (a) to explore the

\footnotetext{
${ }^{14}$ This decomposition result is not sensitive to alternate values of $\alpha_{j}$. When setting $\alpha_{j}=0.5$, as in Reimers (1983), the three factors jointly account for approximately 75 percent of the observed wage growth. When setting $\alpha_{j}=0$, i.e., holding the distribution of individual characteristics at the ending level, the three factors still account for 70 percent of the wage growth during the study period.

${ }^{15}$ As Table 2 shows, the widening gender earnings gap is another significant source of wage growth. We leave this topic for future research, as the study of gender roles and possible discrimination in the labor market is beyond the scope of this paper.
} 
determination of the base wage, in addition to the skill premium; (b) to develop a two-sector model comprising a state and private sector, thereby capturing a key feature of China's economic transition; and (c) to construct proxies for SBTC and to incorporate their role in wage determination. We estimate the parameters of the model structurally by matching wages from the model-implied marginal product schedules to observed wages in the data. Hence, the estimation deploys aggregate time-series input-output data by ownership type and the corresponding wage information from the UHS. Our counterfactual analysis reveals both the explicit mechanisms of wage determination and the relative importance of different economic forces in shaping wage changes in China. ${ }^{16}$

\subsection{Two-Sector Model}

Consider a model with a state sector $(j=s)$ and a private sector $(j=p)$. The aggregate output $Y_{j t}$ for sector $j$ at time $t$ is generated by a two-level constant-elasticity-of-substitution (CES) production function with three inputs: physical capital $\left(K_{j t}\right)$, high-skilled labor $\left(N^{h}\right)$, and low-skilled labor $\left(N^{l}\right)$ :

$$
\begin{aligned}
Y_{j t} & =A_{j t} F_{j}\left(K_{j t}, N_{j t}^{l}, N_{j t}^{h}\right) \\
& =A_{j t}\left\{\mu_{j}\left(N_{j t}^{l}\right)^{\sigma_{j}}+\left(1-\mu_{j}\right)\left[\lambda_{j}\left(K_{j t}\right)^{\rho_{j}}+\left(1-\lambda_{j}\right)\left(N_{j t}^{h}\right)^{\rho_{j}}\right]^{\sigma_{j} / \rho_{j}}\right\}^{1 / \sigma_{j}}
\end{aligned}
$$

where $A_{j t}$ is a factor-neutral technology parameter, and $\left\{\mu_{j}, \lambda_{j}\right\}$ are parameters that govern income shares. In this specification, the elasticities of substitution between capital and low-skilled labor, and between high-skilled labor and low-skilled labor, are the same, with a value of $1 /\left(1-\sigma_{j}\right),{ }^{17}$ whereas that between high-skilled labor and capital is $1 /\left(1-\rho_{j}\right)$, with $\left\{\sigma_{j}, \rho_{j}\right\}<1$. If $\sigma_{j}>\rho_{j}$, then the production technology exhibits capital-skill complementarity.

The labor input of each skill type is measured in efficiency units. We define the skill

\footnotetext{
${ }^{16}$ There are alternative approaches to empirical estimation, which differ in terms of data requirements and emphases. One alternative is to estimate a life-cycle labor supply model under a dynamic general equilibrium framework, similar to Heckman, Lochner, and Taber (1998) and Lee and Wolpin (2010). However, the estimation of this framework requires individual panel data similar to those in the National Longitudinal Survey of Youth (NLSY), which are not available in China. Another alternative is to adopt a regressionbased approach along the lines of Katz and Murphy (1992), which treats major occupational categories of gender-education groups among broadly defined industries as the basic unit of analysis. Their study examines approximately 1.4 million U.S. workers, whereas the sample size of the UHS data is too small to implement similar analysis. The lack of Chinese data on industry-level capital stock is an additional limitation.

${ }^{17}$ This specification is supported by recent studies on capital-skill complementarity, including those of Goldin and Katz (1998), Krusell et al. (2000), Caselli and Coleman (2002), and Duffy, Papageorgiou, and Perez-Sebastian (2004). The alternative specification of setting the same elasticities of substitution between $N^{h}$ and $N^{l}$ and $N^{h}$ and $K$ appears to be inconsistent with empirical estimates (see Hamermesh, 1993).
} 
level of labor input by workers' educational attainment, with low-skilled labor matched to middle school graduates and high-skilled labor requiring a high school or college education. Following Krusell et al. (2000), we define the efficiency labor units of each type as a product of worker numbers and their efficiency index: $N_{j t}^{l}=\psi_{t}^{l} n_{j t}^{l}$ and $N_{j t}^{h}=\psi_{t}^{h s} n_{j t}^{h s}+\psi_{t}^{c} n_{j t}^{c}$, where $\left\{n_{j t}^{l}, n_{j t}^{h s}, n_{j t}^{c}\right\}$ are the numbers of middle school, high school, and college workers in sector $j$ at date $t$, and $\left\{\psi_{t}^{l}, \psi_{t}^{h s}, \psi_{t}^{c}\right\}$ constitute the unmeasured quality of workers of each type. The $\psi^{\prime} s$ can be interpreted as education-specific labor-augmenting technology levels, which are assumed to be equal across sectors.

A major institutional factor that is incorporated into our analysis is employment protection under the central planning regime and the subsequent relaxation of control during the economic transition. Prior to reform, with the government's goal to achieve full employment, SOEs served as guarantors of their employees' job security and welfare. During the initial period of reform, employment protection for low-skilled workers remained pervasive because it was thought that mass layoffs from inefficient SOEs might lead to social instability. Based on detailed data, Dong and Putterman (2003) estimate that the labor redundancy rate of SOEs was nearly 33 percent in 1992. To model overstaffing in the state sector in the early years of reform, we assume that the observed number of low-skilled workers subject to protection $\left(\overline{n^{l}}\right)$ exceeded the employment level that would prevail under competitive conditions. Beginning in 1997, however, when China launched its restructuring program to privatize SOEs, state-protected employment $\overline{n^{l}}$ gradually declined, eventually converging to the competitive level. ${ }^{18}$ Given the social burden of the state sector, its production function becomes

$$
Y_{s t}=A_{s t}\left\{\mu_{s}\left(\overline{N_{t}^{l}}\right)^{\sigma_{s}}+\left(1-\mu_{s}\right)\left[\lambda_{s}\left(K_{s t}\right)^{\rho_{s}}+\left(1-\lambda_{s}\right)\left(N_{s t}^{h}\right)^{\rho_{s}}\right]^{\sigma_{s} / \rho_{s}}\right\}^{1 / \sigma_{s}},
$$

where $\overline{N_{t}^{l}}=\psi_{t}^{l} \overline{n_{t}^{l}}$ is the state-managed level of low-skilled labor in efficiency units.

By contrast, the Chinese government has directly intervened in the market for high-skilled labor to a very limited extent. Workers with a high level of schooling often boast strong social networks, good information skills, and the ability to switch jobs, and therefore are more mobile and less vulnerable to layoffs during periods of transition. ${ }^{19}$ Hence, we assume

\footnotetext{
${ }^{18}$ The layoffs resulting from SOE restructuring primarily affected low-skilled workers, with the fraction of employees with a middle school education declining from 33.8 percent in 1992 to 13.3 percent in 2007 in the state sector. This skill composition shift was driven only partially by the skill-upgrading of the urban workforce, as the fraction of low-skilled workers in the overall urban workforce decreased at a much slower pace (see Table 1).

${ }^{19}$ Knight and Yueh (2004) find that the mobility rates of urban residents increase with their education. In a related study, Li (1998) discusses the phenomenon known as xiahai (i.e., "jumping into the sea") since the late 1980s, when the better educated state employees or officials quit their government positions to join the business sector. This description is consistent with the empirical finding that labor markets for engineers
} 
that high-skilled workers are mobile across the state and private sectors. However, because state employment protection for unskilled labor and favorable capital allocation generate a wage differential across the two sectors, the complete wage equalization of skilled workers does not occur naturally. Consistent with the specification in equation (1), we specify equal skill premiums for high school and college graduates across the state and private sectors. ${ }^{20}$ Therefore, given that the capital markets across the two sectors are segmented (Bai, Hsieh and Qian, 2006; Song, Storesletten and Zilibotti, 2011) and that capital stocks are determined exogenously by long-term accumulations, the equilibrium allocation of high-skilled labor in the state sector $N_{s t}^{h}$ at date $t$ is determined by the following implicit function.

$$
\begin{aligned}
& \frac{\eta_{s}}{\mu_{s}}\left[\lambda_{s}\left(\frac{K_{s t}}{N_{s t}^{h}}\right)^{\rho_{s}}+\left(1-\lambda_{s}\right)\right]^{\frac{\sigma_{s}}{\rho_{s}}-1}\left(\frac{N_{s t}^{h}}{\overline{N_{t}^{l}}}\right)^{\sigma_{s}-1} \\
= & \frac{\eta_{p}}{\mu_{p}}\left[\lambda_{p}\left(\frac{K_{p t}}{N_{t}^{h}-N_{s t}^{h}}\right)^{\rho_{p}}+\left(1-\lambda_{p}\right)\right]^{\frac{\sigma_{p}}{\rho_{p}}-1}\left(\frac{N_{t}^{h}-N_{s t}^{h}}{N_{t}^{l}-\overline{N_{t}^{l}}}\right)^{\sigma_{p}-1},
\end{aligned}
$$

where $\eta_{j}=\left(1-\mu_{j}\right)\left(1-\lambda_{j}\right)$ and $\left\{N_{t}^{h}, N_{t}^{l}\right\}$ are the total efficiency units of high and low-skilled labor in the workforce. Combined with the allocation of capital and low-skilled labor across the two sectors, this condition helps to pin down all of the aggregate factor inputs used in the production functions.

Reforms were carried out within the state and private sectors as early as the mid-1980s to align wages with worker productivity. The implementation of incentive schemes suggests that workers' wages can be assessed on the basis of marginal product conditions. Consistent with earlier empirical analysis, we define the base wage as the earnings of low-skilled labor in the private sector $w_{p t}^{l}$, which can be derived as

$$
w_{p t}^{l}=\mu_{p} A_{p t}^{\sigma_{p}} Y_{p t}^{1-\sigma_{p}}\left(N_{t}^{l}-\overline{N_{s t}^{l}}\right)^{\sigma_{p}-1} \psi_{t}^{l}
$$

Equation (8) shows that the base wage is determined by several factors. Because $\sigma_{p}<$ 1 , greater output in the private sector $\left(Y_{p t}\right)$, through either capital deepening or export expansion, may push up the wages of the unskilled. As expected, the base wage is also positively dependent on general technological efficiency $\left(A_{p t}\right)$, the quality of low-skilled labor $\left(\psi_{t}^{l}\right)$, and its factor share parameter $\left(\mu_{p}\right)$. By contrast, ceteris paribus, an increase in the supply of low-skilled labor in the private sector $\left(N_{t}^{l}-\overline{N_{s t}^{l}}\right)$ reduces the base wage.

and managers were developed more than those for production workers in the 1990s (Lee, 1999).

${ }^{20}$ See footnote 11 for additional explanations. More specifically, when paired interaction terms are added to equation (1) for all years under study, most of the coefficients for the interaction between schooling levels and the state-sector dummy variables are statistically insignificant, revealing equal skill premiums across the state and CIP sectors. 
The skill premium is defined as the wage of high-skilled labor relative to that of low-skilled labor. Given that skill premium levels do not differ statistically across the two sectors, the college premium can be expressed as

$$
\frac{w_{p t}^{c}}{w_{p t}^{l}}=\frac{\eta_{p}}{\mu_{p}} \frac{\psi_{t}^{c}}{\psi_{t}^{l}}\left(\frac{N_{t}^{h}-N_{s t}^{h}}{N_{t}^{l}-\overline{N_{s t}^{l}}}\right)^{\sigma_{p}-1}\left[\lambda_{p}\left(\frac{K_{p t}}{N_{t}^{h}-N_{s t}^{h}}\right)^{\rho_{p}}+\left(1-\lambda_{p}\right)\right]^{\sigma_{p} / \rho_{p}-1} .
$$

The high school premium can be defined similarly. Aside from income share parameters $\left\{\eta_{p}, \mu_{p}\right\}$, equation (9) explicates three determinants of the college premium. First, this premium depends positively on the efficiency of college workers relative to middle school workers, $\left(\psi_{t}^{c} / \psi_{t}^{l}\right)$. Second, it is determined by the ratio of high-skilled labor to low-skilled labor, $\left(N_{t}^{h}-N_{s t}^{h}\right) /\left(N_{t}^{l}-\overline{N_{s t}^{l}}\right)$. As $\sigma_{p}<1$, the relative growth of high-skilled labor reduces the skill premium. Third, capital deepening is another important factor driving the relative wage. When there is capital-skill complementarity $\left(\sigma_{p}>\rho_{p}\right)$, a rise in capital to high-skilled labor ratio $K_{p t} /\left(N_{t}^{h}-N_{s t}^{h}\right)$ raises the college premium.

Finally, we define the state-sector wage premium as the ratio of low-skilled wages (or, equivalently, the ratio of high-skilled wages) in the state sector relative to those in the private sector:

$$
\frac{w_{s t}^{l}}{w_{p t}^{l}}=\frac{\mu_{s}\left(A_{s t}\right)^{\sigma_{s}}\left(Y_{s t}\right)^{1-\sigma_{s}}\left(\overline{N_{s t}^{l}}\right)^{\sigma_{s}-1}}{\mu_{p}\left(A_{p t}\right)^{\sigma_{p}}\left(Y_{p t}\right)^{1-\sigma_{p}}\left(N_{t}^{l}-\overline{N_{s t}^{l}}\right)^{\sigma_{p}-1}} .
$$

Hence, given the economy's capital stock and labor force in period $t$, the state-sector wage premium depends on three relative quantities across the state and private sectors: technological efficiency, output levels, and the allocation of low-skilled labor. In particular, when SOE restructuring slashes the number of low-skilled workers in that sector, ceteris paribus, the state wage premium increases accordingly.

\subsection{Quantitative Analysis}

We now employ the two-sector model to analyze quantitatively the driving forces behind the observed changes in the base wage and wage premiums. With the estimates obtained for the production function parameters, equations (8), (9), and (10) can be used to assess the way in which various economic forces affect the base wage and wage premiums. We proceed with this analysis in four steps: (A) specification of the empirical model, (B) variable measurement

using supplemental aggregate data, (C) parameter estimation with robustness checks, and (D) counterfactual analysis of wage determination.

\section{A. Empirical Specification}

The efficiency of a worker with education level $k \in\{l, h s, c\}$ is given by index $\psi_{t}^{k}$. Although 
unobservable to the econometrician, we specify this index as a linear function of an initial efficiency level at the beginning of the sample $\left(\psi_{0}^{k}\right)$, labor-augmenting technological change $\left(\right.$ LATC, $\left.\gamma^{k} X_{t}\right)$, and a stochastic factor $\left(\omega_{t}^{k}\right)$ :

$$
\psi_{t}^{k}=\psi_{0}^{k}+\gamma^{k} X_{t}+\omega_{t}^{k}
$$

where the education-specific coefficient $\gamma^{k}$ captures the idea that LATC may exert differential (or biased) effects on the efficiency of different skill types. We consider domestic R\&D and capital flows from abroad as two sources of technological advances (Griliches, 1979; Feenstra and Hanson, 1997). Following the methods first proposed by Griliches (1979), we adopt the perpetual inventory method (PIM) to construct the stocks of domestic R\&D and FDI as proxies for $X_{t}$, as explained in Appendix B. The $\omega_{t}^{k} s$ are assumed to be normally distributed i.i.d. shocks with zero mean, zero covariance, and identical variances, which implies that covariance matrix $\Omega=\eta_{\omega}^{2} I_{3}$, where $\eta_{\omega}^{2}$ is the common innovation variance and $I_{3}$ is the $3 \times 3$ identity matrix. Given the small sample size with which we are working, these restrictions are necessary to reduce the number of parameters to be estimated.

The econometric model comprises four structural wage equations derived from the twosector model. These four equations represent the base wage, the high school and college premiums, and the state-sector wage premium:

$$
\begin{aligned}
\left(w_{p t}^{l}\right)^{U H S} & =w_{p t}^{l}\left(Z_{t} ; \theta\right), \\
\left(\frac{w_{p t}^{h s}}{w_{p t}^{l}}\right)^{U H S} & =\frac{w_{p t}^{h s}}{w_{p t}^{l}}\left(Z_{t} ; \theta\right), \quad\left(\frac{w_{p t}^{c}}{w_{p t}^{l}}\right)^{U H S}=\frac{w_{p t}^{c}}{w_{p t}^{l}}\left(Z_{t} ; \theta\right), \\
\left(\frac{w_{s t}^{l}}{w_{p t}^{l}}\right)^{U H S} & =\frac{w_{s t}^{l}}{w_{p t}^{l}}\left(Z_{t} ; \theta\right),
\end{aligned}
$$

where $Z_{t} \equiv\left\{Y_{s t}, Y_{p t}, K_{s t}, K_{p t}, n_{t}^{l}, n_{t}^{h s}, n_{t}^{c}, \overline{n_{t}^{l}}, X_{t}\right\}$ is the vector of exogenous variables including output by sector, factor inputs, and measures of technological change. Parameter vector $\theta$ has 18 components: curvature parameters $\sigma_{j}$ and $\rho_{j}$, which govern the elasticities of substitution; income share parameters, $\lambda_{j}$ and $\mu_{j}$; the initial values of labor efficiencies, $\psi_{0}^{k}$; labor efficiency coefficients $\gamma^{k}$; and the variance of labor efficiency shocks $\eta_{\omega}^{2}$.

The left-hand sides of the structural equations are the empirical base wage and wage premiums estimated from the UHS sample, and the right-hand sides are their theoretical counterparts from the model. We employ the simulated method of moments (SMM) to estimate the 18 parameters, relying on $4 \times 16=64$ moments generated from the 16-year period. The weighted average distance between the sample moments from the UHS and 
simulated moments from the model is minimized with respect to the model parameters. Appendix C provides details of the SMM estimation including the weighting procedure.

\section{B. Measurement of Aggregate Variables}

Although the empirical moments of the base wage and wage premiums in equations (12)(14) can be computed using the UHS data, the model-generated moments require aggregate time-series data on $Z_{t}$ from 1992 to 2007, which comprise output values, factor inputs, and the proxies of LATC in both the state and non-state sectors. For empirical analysis, we define the non-state sector (or private sector) as comprising collective enterprises and all domestic individual and private enterprises, which is the same as the CIP group in earlier analysis. Using data from the Statistical Yearbook of China (SYC), we measure output $\left(Y_{j t}\right)$ as real GDP in 2007 yuan in each of the two sectors. The state sector's output share of GDP declines over time, consistent with the trend in employment documented in Table 1. The output value of this sector was larger than that of the private sector by more than three fold in 1992, but by 2007 it was just 38 percent larger. During the study period, the average output growth rate of the private sector hovered around 12.6 percent per year, far exceeding the 6.2 percent annual growth rate of the state sector.

The construction of the capital stock series $\left(K_{j t}\right)$ in real prices is based on the PIM approach and uses a long series of capital investment data from published sources, including the "Statistical Yearbook of Fixed Assets Investments." As Appendix B explains, our construction of capital stock figures builds on the well-regarded work of Sun and Ren (2005), who take into account capital investment by type and adopt depreciation schedules suitable to the Chinese economy. Our constructed data series reveals the rapid growth of capital stocks in the state sector during the 1992-1998 period. However, following the subsequent state-sector restructuring beginning in the late 1990s, the growth rate of capital stocks in the private sector surpassed that in the state sector during the 1999-2007 period.

With regard to labor inputs $\left\{n_{t}^{k}\right\}$, the basic data are urban employed workers by ownership category. However, additional information is needed to implement the estimation: (a) the distribution of urban workers by educational attainment, and (b) the number of rural-to-urban migrants, as they are part of the urban labor supply but their size is underrepresented in the UHS. We employ the national sample of the UHS to impute the proportion of workers in each of the educational categories and estimate the size of the rural-to-urban migrant workforce based on the 2000 and 2005 Population Censuses. Our estimates reveal a strong upward trend in the supply of high-skilled workers relative to that of low-skilled workers over the 1992-2007 period. The ratio of workers with a high school education to those with a middle school education increased by 54 percent during the period, and that of 
employees with a college education to those with a middle school education increased by 215 percent. Moreover, despite increases in both skilled labor and capital inputs, the capital to high-skilled labor ratio grew continuously over the study period. The rise in capital intensity raised the skill premium through capital-skill complementarity, as suggested by equation (9). Finally, we also compile stock measures of domestic R\&D and FDI to approximate LATC $\left(X_{t}\right)$, as previously discussed, and collect sector-specific export data to assess the effect of globalization on wages. Appendix B provides more detailed descriptions of the construction of these aggregate variables.

\section{Parameter Estimates}

The estimation of the benchmark model takes the stocks of capital and labor variables in $Z_{t}$ as exogenous, which is a standard assumption in growth accounting. However, because date $t$ capital investment and the participation of skilled and unskilled labor may respond to date $t$ realizations of technology and labor quality shocks, the capital and labor variables are potentially endogenous. We first present the findings from the benchmark model and then examine the sensitivity of the results to an alternative instrumental variable (IV) procedure.

Table 3 reports the estimates of the key model parameters and their standard errors (SE). The results show that $\sigma_{j}>\rho_{j}$, i.e., production exhibits capital-skill complementarity in both sectors. More specifically, the estimated substitution elasticities between low-skilled labor and capital (and, by symmetry, high-skilled labor) are $1 /\left(1-\sigma_{s}\right)=2.48$ in the state sector and $1 /\left(1-\sigma_{p}\right)=2.31$ in the private sector, whereas those between high-skilled labor and capital are $1 /\left(1-\rho_{s}\right)=1.44$ and $1 /\left(1-\rho_{p}\right)=1.51$, respectively, in the two sectors. There appears to be no substantial differences in the estimated elasticities across the two sectors. Moreover, these estimates for China are well within the reasonable range found in the empirical literature (Hamermesh, 1993) and are close to those reported in crosscountry studies (Duffy, Papageorgiou and Perez-Sebastian, 2004). With regard to worker quality, technological change, as measured by R\&D expenditures and inflows of FDI, is found to enhance the efficiency of labor significantly, and the size of this effect increases with educational attainment. In other words, LATC in China is indeed biased toward high-skilled labor.

Factor-neutral efficiency levels, $A_{s t}$ and $A_{p t}$, can be derived as residuals using the estimated parameters and observed input and output data based on the production functions. These efficiency parameters are influenced by both technological innovations and the efficiency of resource allocation (Hsieh and Klenow 2009). Our estimation results suggest that the efficiency level in the private sector, $A_{p}$, is about 40 percent higher than that in the state

sector, $A_{s}$, at the beginning of the sample period, and this gap increases to more than 70 
percent after 2004, thus implying a reduction in the relative efficiency of the state sector. Moreover, there have been a declining trend in $A_{s}$ and $A_{p}$ since 1994, a result consistent with the findings of Bai, Hsieh and Qian (2006) and Brandt, Tombe and Zhu (2011), who report that factor market distortions began to increase, and returns to capital to decline, in the mid-1990s in China. Changes in production efficiency affect both wage levels and relative wages in the two sectors.

Given the parameter estimates, we can derive the predictions of the benchmark model and compare them with the base wage and wage premiums observed in the data. Figure 2 shows the estimated model to perform well in predicting all four key variables. Panel A illustrates the model's ability to capture the upward trend in the base wage: the predicted increase in the log wage from 7.61 in 1992 to 8.50 in 2007 closely matches the rise in the observed data from 7.60 to 8.48. Admittedly, the model cannot track all short-period fluctuations effectively. For example, immediately after Deng Xiaoping's southern tour in 1992, private sector output expanded significantly for two consecutive years, effecting a jump in the base wage in the model. In contrast, the increase in the actual base wage was steady and smooth. For the years since China's entry into the WTO in 2001, both the data and the model exhibit accelerated wage growth.

Panels B and C indicate that the predicted high school and college wage premiums closely track the actual school premiums over time. More specifically, the predicted versus actual increases in the high school premium are 0.038 versus 0.055 log points from 1992 to 2007, whereas those for the college premium are 0.287 versus 0.255 . There is a minor mismatch between the two series in that the college premium implied by the model exceeds the actual observations in most years in the $1990 \mathrm{~s}$, a pattern consistent with the view that the rate of returns to education was systematically suppressed during the early years of reform. An interesting emerging trend is that the college premium plateaued in both the data and the model in the last several years of the sample, a period that coincides with the increased supply of college graduates to China's labor market following the dramatic expansion of college enrollment in the late 1990s.

In Panel D, the model predictions for the state-sector wage premium are broadly consistent with the data, although the predicted series exhibits greater fluctuation than the actual changes. More specifically, the model under-predicts the state-sector wage premium from 1992 to 1999, and over-predicts it from 2000 to 2003. The result in the first period is consistent with the view that the government provided systematic wage subsidies to SOE workers in the 1990s. ${ }^{21}$ The subsequent restructuring led to the closure of many loss-making

\footnotetext{
${ }^{21}$ SOEs carried several kinds of policy burdens during the transition. When the government and state firms have wage, employment, and profits in their objective functions, the wage is set above the marginal
} 
SOEs and mass layoffs in those that continue to operate. This process is revealed by the drastic increase in the predicted state-sector wage premium in Panel D, whereas the actual wage adjustment appears to be steadier and smoother. After 2003, with diminished wage subsidies from restructuring, the model and the data converge into a tight fit, thus implying that the ratio of state-sector to private-sector wages reflects relative labor productivity.

We have thus far presented the parameter estimates and model fit based on the assumption that capital stocks and labor supplies are exogenous. Before we proceed to counterfactual analysis, it seems prudent to first check the robustness of our results by relaxing the assumption of exogenous factor inputs. It is true that the capital stocks carried over from earlier periods can be treated as exogenous, but date $t$ capital investment may respond to changing wage conditions and technology shocks, and thus is potentially endogenous. Similarly, labor force participation may also respond to concurrent economic conditions, such as the realization of the technology and labor quality shocks.

To take these potential endogeneity issues into account, we adopt a two-step procedure along the lines of an IV approach. In the first step, we project annual capital investment onto lagged capital stocks and a set of IVs, including military spending, administrative expenditure, and world oil prices, that are correlated with concurrent investment but independent of civilian non-agricultural production. This is essentially the approach taken in Heckman, Lochner and Taber (1998). Then, we construct capital stock series based on the fitted investment values. Moreover, as in Lee and Wolpin (2010), we employ cohort size as an IV for total employment. More specifically, we use the cohort size for women aged 16-55 and that for men aged 16-60, which reflect the rules on mandatory retirement and regulations on working age in China. In the second step, the fitted values for labor supply and the constructed capital stock series are used in the SMM estimation of the parameters. Estimates from this two-step procedure are reported in the last two columns of Table 3. The differences between the benchmark and two-step estimates are negligible. It is evident that the parameter estimates in the benchmark model are not sensitive to alternative IV specifications.

\section{Accounting for Wage Structural Changes}

Profound changes in labor market conditions, characterized by capital accumulation, technological advances, enterprise restructuring, and shifts in the quantity and quality of labor, have influenced China's wage structure. The relative contributions of these factors to the rising base wage and wage premiums can be assessed quantitatively employing the estimated benchmark model. In what follows, we first focus on the effects of changes in factor inputs

product of labor (Lee, 1999). 
on wage growth, and we then extend the analysis to explore the consequences of China's accession into the WTO.

To isolate the quantitative effect of each factor on wage changes over the 1992-2007 period, we perform the following counterfactual analysis. We set 1992 as the base year and hold all factor inputs and technological parameters at their initial levels. With this setup, we analyze how the Chinese wage structure would evolve under alternative scenarios in which some of these factors changed as they did in reality and others underwent no change from their initial levels.

We consider five counterfactual scenarios in which we allow each variable to move from its 1992 base to the 2007 level while holding all other variables at their initial conditions: (1) capital stock accumulates; (2) LATC occurs; (3) the numbers of middle school, high school, and college workers evolve; (4) the employment protection of unskilled labor declines; and (5) the factor-neutral technological level changes. Table 4 presents the results of these counterfactual experiments for wage changes over the 1992-2007 period. The first row reports observed changes in the data in log points for the base wage, schooling premiums, and state wage premium, which serve as a basic reference for comparisons. All of the counterfactual experiments in rows (1)-(5) examine the relative contribution to wage changes of one factor at a time, whereas the last row represents the benchmark outcomes resulting from simultaneous changes in all five factors.

Between 1992 and 2007, the measured capital stocks increased by 2.8 times in the state sector and by 6.9 times in the private sector. Combining these figures, the share of capital investment in GDP increased from 26.4 percent to 51.9 percent. To assess the effects of capital deepening, the first experiment in row (1) allows these changes in capital stocks in each sector while keeping all of the other variables at their 1992 levels. Capital accumulation by itself would have led to a 0.834 log-point increase in the base wage, a 0.386 such increase in the high school and college premiums, and a 0.333 such decrease in the state-wage premium. Capital deepening enhances the marginal product of labor when employment is held constant, causing wages to rise for all types of labor. Moreover, an increase in the capital-labor ratio raises the school premium, as shown in equation (9), because capital is more complimentary to high-skilled labor $\left(\sigma_{j}>\rho_{j}\right)$. However, the state wage premium declines because capital accumulated at a faster pace in the private than state sector during the sample period.

Domestic R\&D expenditures and FDI are used as proxies for technological innovations. Parameter estimation suggests that technological advances in China are biased toward welleducated workers. In the second experiment in row (2), the observed changes in R\&D expenditures and FDI alone would have led to a 0.659 log-point increase in the base wage because of improvements in labor quality. As SBTC exerts a larger efficiency effect on high 
school workers than on their middle school counterparts $\left(\gamma^{h s}>\gamma^{l}\right)$, and an even larger effect on college workers $\left(\gamma^{c}>\gamma^{h s}\right)$, such change creates an upward force on schooling premiums. However, labor efficiency units increase in the efficiency coefficients, and thus the relative supply effect $\left(N_{t}^{h}-N_{s t}^{h}\right) /\left(N_{t}^{l}-\overline{N_{s t}^{l}}\right)$ tends to suppress these premiums, as shown in equation (9). Overall, these two combined effects of increases in R\&D expenditures and FDI would have led to a 0.038 log-point increase in the high school premium and a 0.287 such increase in the college premium. ${ }^{22}$ Their effect on the state-wage premium is positive, but negligible.

The employment share of workers with a middle school education declined persistently, as the urban workforce continually upgraded its skills from 1992 to 2007 . At the same time, the number of low-skilled rural migrants has increased gradually since the early 1990s, offsetting the reduction in comparable workers in cities. In total, the number of low-skilled workers declined only slightly over the sample period, from 70.9 million in 1992 to 69.7 million in 2007. The number of employed workers with a high school education increased up to 1997 and then declined thereafter, whereas the number of college-educated workers continued to increase throughout the period. In row (3) of Table 4, we allow for these actual changes in the composition of the workforce over time, while holding the other variables at their 1992 base values. Because the number of low-skilled workers declined slightly, the base wage would rise marginally. The high school and college premiums would have declined by 0.157 $\log$ points because of the increase in the supply of high-skilled workers.

Economic restructuring in the late 1990s led to large-scale layoffs of redundant workers in the state sector. The experiment in row (4) considers the relaxation of state employment protection. Holding the other factors constant, the observed decline in state employment $\left(\overline{n^{l}}\right)$ is associated with the release of low-skilled workers into the private sector, which would have led to a -0.206 log-point reduction in the base wage. Lower wages would have facilitated private sector growth, and the allocation of high-skilled labor across the two sectors would have adjusted to restore the equilibrium. In equation (9), both the high to low-skilled labor ratio and the capital to high-skilled labor ratio undergo adjustment, and the net effect is to reduce the skill premium by -0.225 . In our model, economic restructuring plays a major role in boosting labor productivity in China's SOEs, and is a major driving force of the rise in the state-wage premium. ${ }^{23}$

\footnotetext{
${ }^{22}$ These results are consistent with empirical findings based on firm-level data showing that R\&D has significant and positive effects on productivity in Chinese industries (Hu, Jefferson and Qian, 2005). These authors also find evidence of complementarity between $R \& D$ and both domestic and foreign technology transfer variables.

${ }^{23}$ An alternative explanation for the increasing state premium draws on the housing provision and healthcare subsidies accruing to SOE workers in the early 1990s (see Zhao, 2002; Wang, 2011). As reform progressed, these subsidies are likely to have been converted into monetary wages over time, thus raising the wages of SOE workers relative to their counterparts in the CIP sector. Although data on non-wage subsidies
} 
In row (5), we consider the effects of other non-measured factors on wage growth. Because of the downward trend in $A_{j}$, and the moderate decline for the private sector, this factor alone would lead to a reduction in the base wage and the state premium.

The last row of Table 4 presents the changes in the wage level and relative wages in the benchmark model by combining the effects of all five factors considered in these experiments. Overall, capital accumulation through the mechanism of capital-skill complementarity and SBTC are the two major forces driving up the base wage and skill premiums, whereas changes in the labor supply and enterprise reform exert downward pressure on these premiums. SOE restructuring is the main driving force behind the rise in the state-wage premium.

Thus far, our counterfactual experiments have explored the effects of factor input changes on wage growth. We now turn to an exploration of the wage effects of China's WTO accession in 2001, which led to rapid expansion in the export of manufactured goods. Our benchmark model of aggregate production does not allow for nuanced analysis of the increased demand for Chinese labor arising from exports along the lines of Katz and Murphy (1992), who estimate the by-industry labor supply embodied in net imports of manufactured goods in the U.S. Instead, we investigate wage structural changes in three counterfactual scenarios, treating exports simply as a component of outputs. Holding constant all other 2007 conditions, we reduce three trade variables to their 2001 level, namely, (1) export volume, (2) total domestic value-added embodied in exports, and (3) the trade surplus. Our objective is to determine how the base wage and wage premiums respond to a reduction in exports, and thus to the reduction in factor inputs required to produce the corresponding outputs.

After its WTO accession, China's annual export volume grew by more than 28 percent over the 2001-2007 period. In scenario (1), we set export volume to its 2001 level, while holding the other conditions at their 2007 level, thus allowing us to ignore all indirect inputout effects. Because exports are a component of output, $Y_{p}$ drops when export volume takes a lower value, as shown in equation (8). Consequently, we have the following expression for the change in the log base wage over time.

in the state sector are sparse, we find no supporting evidence for this alternative hypothesis using indirect UHS data. First, workers in the CIP sector are likely to have received similar housing subsidies as state workers because: (1) municipalities allocated funds to develop public housing for workers employed in small and street-level enterprises, amounting to 27 percent of the total public housing budget in 1988, and (2) some collective enterprises, especially large ones controlled by the state, did provide housing to their employees (Wu, 1996). Second, using the UHS data, we find state and CIP-sector workers to have almost the same time-series patterns of expenditure on housing and health care, conditional upon household income. There is no evidence of state-sector workers receiving more subsidies than their CIP-sector counterparts. These results are available from the authors upon request. 


$$
\begin{aligned}
\ln w_{p t+1}^{l}-\ln w_{p t}^{l} & =\left(1-\sigma_{p}\right)\left(\ln Y_{p t+1}-\ln Y_{p t}\right) \\
& =\left(1-\sigma_{p}\right)\left\{\ln \left[x_{p t+1} Y_{p t+1}+\left(1-x_{p t+1}\right) Y_{p t+1}\right]-\ln \left[x_{p t} Y_{p t}+\left(1-x_{p t}\right) Y_{p t}\right]\right\}
\end{aligned}
$$

where $\left(x_{p t}, x_{p t+1}\right)$ denote the share of exports in total output. This expression distinguishes the production for external demand $\left(x_{p} Y_{p}\right)$ from that for the domestic market $\left(1-x_{p}\right) Y_{p}$. For simplicity of exposition, we consider the output produced by state and non-state firms to be homogeneous and output for domestic sale and export to be substitutable. Hence, the share of exports in date $t$ output can be computed as

$$
x_{p t}=x_{s t}=\frac{X_{p t}+X_{s t}}{Y_{p t}+Y_{s t}},
$$

where $X_{j t}$ represents the exports in sector $j$. This expression encompasses the idea that the influence of trade spreads across the two sectors, i.e., if one sector exports more, then the other takes up the slack in the domestic market. Therefore, export expansion has an aggregate effect rather than sector-specific effect on the base wage.

The increase in exports between 2001 and 2007 can be measured as $\Delta X=x_{p 07} Y_{p 07}-$ $x_{p 01} Y_{p 01}$. Therefore, the changes in the log base wage that are due to export expansion can be assessed numerically as

$$
\Delta \ln w_{p}^{l}(\Delta X)=\left(1-\sigma_{p}\right)\left\{\ln \left[x_{p 07} Y_{p 07}+\left(1-x_{p 07}\right) Y_{p 07}\right]-\ln \left[x_{p 01} Y_{p 01}+\left(1-x_{p 07}\right) Y_{p 07}\right]\right\}
$$

where we set domestic output sales to the 2007 level in the last group of terms on the righthand-side, with the aim to isolate the contribution of export expansion to wage change. When exports are set to the 2001 level, and all else is held constant, the base wage is $0.124 \log$ points lower than the 2007 benchmark. By these measures, export expansion is a significant driving force behind the rising base wage in China.

Using a similar approach, we also compute the effect of trade expansion on the statewage premium in the post WTO era. Because the rise in output stemming from export expansion is faster-paced in the private than state sector, an increase in exports reduces the state-wage premium by 0.041. Note that export expansion has a neutral effect on the education premiums because relative wages are independent of the production scale in our model, which considers a single final good. ${ }^{24}$

\footnotetext{
${ }^{24}$ In other words, the model does not accommodate the effect of international trade on relative wages through the Stopler-Samuelson channels based on factor input intensity. Instead, relative wages are deter-
} 
Measuring trade expansion by export volume may overstate external demand because processing exports have exceeded 50 percent of total exports in China since 1996 (Koopman, Wang and Wei, 2008). By definition, imported raw materials and intermediate inputs are used in the processing trade, accounting for a high proportion of export value. ${ }^{25}$ Accordingly, we employ the growth of value added embodied in exports as a measure of net exports in scenario (2). Using the domestic content shares estimated by Koopman, Wang and Wei (2008), we compute the value-added measures in both sectors and replace the changes in total exports by the changes in domestic value-added in total exports in equations (15) to (17). When this value-added measure is set to the 2001 level, the base wage is $0.093 \log$ points lower, and the state premium 0.028 log points higher, than the 2007 benchmark. Again, we find China's trade expansion to exert significant wage effects.

A second alternative measure for export-induced external demand is the growth in China's trade surplus in the post-WTO period. In 2001, China had a modest export surplus of 1.7 percent of GDP. However, this surplus jumped to 7.8 percent of GDP in 2007 (NBS, 2008). In scenario (3), when we reset net exports in 2007 to the 2001 level, similar to our approach of reducing total exports in scenario (1), we find that the base wage would be $0.027 \log$ points lower, and the state premium 0.004 log points higher, in this counterfactual situation. In other words, a rise in net exports amounting to 6.1 percent of GDP would result in a 2.7 percent increase in China's wage level. According to the calculations of Koopman, Wang and Wei (2008), nearly 80 percent of Chinese imports constitute intermediate inputs and less than 2 percent of total imports are for final consumption. Therefore, growth in net exports is likely to be associated with an increase in external demand rather than import replacements.

In summary, the three trade expansion scenarios associated with China's WTO accession result in 12.4, 9.3, and 2.7 log-point increases in China's base wage. Although each scenario attempts to measure a specific aspect of trade expansion, all three indicate significant positive effects on the economy's wage growth.

An important factor in China's sustained trade growth is the country's large pool of low-cost rural labor. Between 2001 and 2007, the total number of low-skilled rural migrants working in cities increased by 14.3 million, which played an important role in containing the acceleration of wage growth. If we hold the size of the rural migrant workforce constant at the 2001 level, while holding all other variables at their 2007 level, then the base wage is

mined by SBTC and capital-skill complementarity in our model.

${ }^{25}$ By combining detailed trade statistics with input-output tables, Koopman, Wang and Wei (2008) estimate the domestic content share of China's exports to be about 50 percent. More specifically, the share of domestic value-added is about 80 percent in private firms, 70 percent in state-owned firms, 44 percent in joint-venture firms, and 30 percent in foreign firms. These ratios remain relatively constant over time. 
$0.075 \log$ points higher than the 2007 reality. At the same time, the education premiums are pushed down by 0.061 log points because of the relative abundance of high-skilled labor. The large inflow of rural migrants thus helps to explain the relatively moderate growth in China's base wage and the rapid rise in the schooling premium over the past decade.

\section{Conclusion}

In this paper, we document the fundamental changes in China's wage and employment structures during a period of extraordinary economic growth. Our empirical findings suggest that persistent increases in the base wage, rising returns to human capital, and a higher state-sector wage premium are the major components of the country's wage growth. Other factors, such as changes in worker characteristics, the gender composition of the labor force, and the reallocation of workers across industries and regions, have made relatively minor contributions to such growth. The major driving forces behind both wage growth and rising wage inequality in China are capital accumulation, SBTC, and the expansion in external demand for exports. Combined with capital-labor and capital-skill complementarity, demand factors have more than offset the effect of an increased supply of unskilled and skilled labor, thereby pushing up wages.

Our analysis illustrates the multi-faceted nature of labor market adjustments in China. Over the past two decades, rising returns to education have been associated with greater college enrollment and an increase in the quality of the labor force. Interestingly, women's relative earnings have declined in this period, as has their labor market participation. Along with rapid economic growth, the employment share of the service sector has risen, whereas that of the manufacturing sector has fallen, despite China's emergence as the workshop of the world. Moreover, during this process, the non-state sector has expanded, and labor has flown continuously to the high-productivity and high-wage regions. Viewed through the lens of the labor market, these structural changes reveal vivid details of the process of economic growth.

The present study focuses on the operation of the labor market in China. However, globalization and economic transition have seen many other emerging economies also experience fast-paced economic growth. Although the institutional conditions of these countries may exhibit marked differences from their counterparts in China, many of the fundamental

forces governing the growth process are likely to be similar. Whether the driving forces of wage growth identified in the Chinese context can explain wage structure changes in other fast-growing economies remains an important topic for future research. 


\section{Appendix: Data and Estimation Procedures}

\section{A. Urban Household Surveys}

Sample Inclusion Criteria. Our wage sample includes full-time wage and salary workers aged 16-55 (females) and 16-60 (males), the lower and upper limits of the official working ages in China. Excluded from the sample are employers, self-employed individuals, farm workers, retirees, students, those re-employed after retirement, and workers with real annual wages less than half the real minimum wage. Province-level minimum wages are compiled from data released by China's provincial or municipal Ministries of Human Resources and Social Security.

Aggregation of Worker Groups. The UHS record detailed information on school completion levels, enterprise ownership class, industry coding, and residential location by province. To conduct the analysis carried out in this paper, we perform the following aggregation.

(a) Education: Workers are grouped into the categories of "middle school and below," "vocational and high school," with vocational school usually requiring two years of post middle school education in China, and "college and university," which consists of attendees and graduates of four-year universities, three-year specialized colleges, and those who obtained government-recognized college-equivalence diplomas by taking post-secondary night classes or online courses or participating in other remote training programs.

(b) Ownership type: Workers in the sample report various ownership categories for their employers: individually owned, private, collectively owned, state-owned enterprises (SOEs), or other ownership categories, including joint-venture companies, stock-holding firms, and wholly foreign-owned firms (JSF). While maintaining the SOE and JSF categorization, we combine collective, individual, and private firms into a CIP group because worker characteristics across these firm types are almost identical, and the average wages and wage growth patterns are similar. Another reason for this aggregation is that very few people worked in individual/private firms in the early years of the data, accounting for only about 2 percent of the labor force in the 1992-1996 period. It would be difficult to conduct meaningful econometric studies in subsequent analysis if these firms were treated as a separate ownership group.

(c) Industry: We group manufacturing and construction together to represent the secondary sector, and we classify them as the manufacturing industry. Basic services include transportation, storage, postal services, wholesale, retail, food services, real estate, and social services. Advanced services include finance and insurance, health, sports, social welfare, education, cultural services, media, scientific research, miscellaneous technical services, gov- 
ernment administrations, and social organizations.

(d) Region: The Northeast consists of three provinces: Liaoning, Jilin, and Heilongjiang. Central China comprises six provinces: Shanxi, Anhui, Jiangxi, Henan, Hubei, and Hunan. The West consists of 11 provinces and autonomous regions and a municipality: Sichuan, Guizhou, Yunnan, Shaanxi, Gansu, Qinghai, Inner Mongolia, Guangxi, Ningxia, Xinjiang, and Chongqing. Finally, the East comprises 10 provinces and municipalities: Hebei, Jiangsu, Zhejiang, Fujian, Shandong, Guangdong, Hainan, Beijing, Tianjin, and Shanghai. Tibet is excluded because of missing surveys in certain years.

Data Resampling. According to the NBS survey administrators, there are several likely explanations for the oversampling of workers from state and collective enterprises. First, self-reporting may introduce error. For example, when a SOE is restructured and becomes a stock-holding firm or a joint venture, its employees may continue to classify their employer as a SOE, failing to recognize the change in ownership for some time. Second, SOE workers usually work a regular eight-hour day, and thus may have more free time in which to respond to surveys than their private-sector counterparts. Third, the NBS seeks help from employers to persuade workers to participate in the surveys to reduce the nonresponse rate. SOEs and their labor union usually provide more help than other types of firms.

To correct this sampling bias, we randomly resample the data such that the employment share of each ownership category is consistent with the aggregate statistics compiled in "Comprehensive Statistical Data and Materials on 55 Years of New China" and various years of the SYC published by the NBS. More specifically, we denote the annual employment shares of three ownership categories - state-owned firms (SOE), collective and individual/private firms (CIP), and firms with other types of ownership, including joint-venture, stock-holding, and foreign firms (JSF) - as $S_{t} / L_{t}, C_{t} / L_{t}$, and $J_{t} / L_{t}$, where the capital letters represent the aggregate numbers of workers, and $L_{t}$ is the size of the labor force. We denote the sample proportions of workers as $s_{t} / l_{t}, c_{t} / l_{t}$, and $j_{t} / l_{t}$, where the small letters represent the workers in the sample, and $s_{t} / l_{t}>S_{t} / L_{t}, c_{t} / l_{t}<C_{t} / L_{t}$, and $j_{t} / l_{t}<J_{t} / L_{t}$.

Based on the assumption that the survey participation of workers within an ownership type is random, we randomly resample workers and adjust the number of those in each ownership category as follows.

(1) Adjusting $s_{t}$ down by

$$
\frac{s_{t} / l_{t}-S_{t} / L_{t}}{s_{t} / l_{t}} s_{t}
$$

(2) Adjusting $c_{t}$ up by

$$
\frac{C_{t} / L_{t}-c_{t} / l_{t}}{c_{t} / l_{t}} c_{t}
$$


(3) Adjusting $j_{t}$ up by

$$
\frac{J_{t} / L_{t}-j_{t} / l_{t}}{j_{t} / l_{t}} j_{t}
$$

We can show that

$$
\frac{C_{t} / L_{t}-c_{t} / l_{t}}{c_{t} / l_{t}} c_{t}+\frac{J_{t} / L_{t}-j_{t} / l_{t}}{j_{t} / l_{t}} j_{t}=\frac{s_{t} / l_{t}-S_{t} / L_{t}}{s_{t} / l_{t}} s_{t}
$$

The resampled data have the same number of observations for each individual year as they did before the resampling, but the employment share of each ownership category is now consistent with the aggregate statistics. Table A1 presents the sample distribution by ownership type before and after resampling.

Table A1: Percentage Distribution of Sample by Ownership Type

\begin{tabular}{lcccc}
\hline \multirow{2}{*}{} & \multicolumn{4}{c}{ Before resampling } \\
\cline { 2 - 5 } & Total & State (\%) & CIP (\%) & JSF (\%) \\
\hline $1992-1996$ & 143,094 & 83.0 & 15.8 & 1.2 \\
$1997-2001$ & 123,819 & 82.1 & 13.8 & 4.1 \\
$2002-2007$ & 388,459 & 70.6 & 16.1 & 13.2 \\
All years & 655,372 & 75.5 & 15.6 & 8.9 \\
\hline & \multicolumn{4}{c}{ After resampling } \\
\cline { 2 - 5 } & Total & State (\%) & CIP (\%) & JSF (\%) \\
\hline $1992-1996$ & 143,094 & 66.9 & 29.2 & 4.0 \\
$1997-2001$ & 123,819 & 56.3 & 32.7 & 11.1 \\
$2002-2007$ & 388,459 & 39.1 & 39.9 & 21.1 \\
All years & 655,372 & 48.4 & 36.2 & 15.4 \\
\hline \hline
\end{tabular}

\section{B. Aggregate Data}

Real GDP. We combine industrial and tertiary sector GDP collected from the SYC and Industrial Statistical Yearbooks as an estimate of the non-agricultural urban GDP, although these data are not separately available for the state, private, and other sectors for certain time periods. Between 1999 and 2007, industrial value-added outputs are reported by ownership type, whereas only the total outputs by ownership type are available prior to 1999. For the state and private sectors, we compute the share of industrial value-added output in total output above a designated size from 1999 to 2007, and then employ a linear in time projection to impute the fractions for earlier years. These estimated ratios, and total industrial output, are then combined to calculate the ownership-specific industrial value-added between 1992 
and 1998. Because no information is available on ownership-specific GDP or value-added output in the tertiary sector, we apply the state and private sector's shares of total industrial value-added output to both industrial and tertiary GDP to construct ownership-specific output. All nominal outputs are deflated by the urban CPI in 2007 yuan.

Capital Stock. Our main data sources for capital stock are the SYC and the Statistical Yearbook of Fixed Assets Investments. Capital investment data can be obtained for the whole economy, for urban areas, and for the state-owned, collective, and private ownership categories. For each ownership category, investments in three categories, "construction and installation" (construction), "purchase of equipment, tools and instruments" (equipment), and "others," are reported separately. The "others" category has no specific definition and consists of a relatively small fraction (between 10 and 16 percent) of total investments and so we split it into construction and equipment using the corresponding shares of each. Construction and equipment investment data for the private sector are missing for the 20002002 period, and so we adopt a linear interpolation using data for 1999 and 2003.

We adopt the PIM to construct capital stock time series using the capital investment data. Employing the PIM, gross capital stock is calculated as the weighted average of gross fixed capital formation in previous years, of which the service life has not yet expired. The weights constitute the relative efficiency of capital investments of different vintage. In the formula, $A_{t}=\sum_{\tau=0}^{T} d_{\tau} I_{t-\tau}$, where $A_{t}$ denotes gross capital stock at time $t, I_{t}$ represents gross capital investment, $d_{\tau}$ is the relative efficiency of a capital investment of vintage $\tau$, and $T$ denotes the expected service life. If the relative efficiency of capital investment declines geometrically, then gross capital stock at time $t$ can be estimated by $A_{t}=(1-\delta) A_{t-1}+I_{t}$, where $\delta$ is the capital depreciation rate.

Although fairly reliable statistics on capital investment are available, statistics on capital retirement are rare. Based on estimates from other countries and suggestions from NBS experts, we assume the service life of equipment to be 16 years and that of construction to be 40 years. Given these assumptions, the depreciation rates for equipment and construction are $17 \%$ and 8\%, respectively. Sun and Ren's (2005) estimates of capital stocks in 1992 are adopted as our base-year figures. Price indices of investments in construction and equipment are available from the SYC. All nominal units are deflated by type-specific price indices to 2007 values. We construct time series of capital stocks of construction and equipment using their separate depreciation rates for each ownership category. Finally, construction and equipment capital stocks are summed to obtain the total capital stock in the state and private sectors.

Labor Input. To estimate employment size by skill type in China's urban labor market, we first collect SYC data on the total number of urban employed workers in each ownership 
category. However, workers' education distribution cannot be ascertained from the aggregate data source. Therefore, we calculate the proportion of workers at each education level (middle school and below, vocational and high school, and college and university) in the state and private sectors from the national UHS sample. Then, we use the employment share by education level and total employment in each sector to compute the number of workers with different levels of educational attainment in each sector. Finally, the total high and lowskilled labor inputs are generated by aggregating the number of middle school, high school, and college workers across the state and private sectors.

One caveat concerning our labor input measure is that the SYC aggregate urban employment statistics exclude rural-to-urban migrant workers (Yue, 2005). The NBS did not sample households in urban areas that lacked urban registrations before 2002. In that year, it expanded the sample coverage of the UHS to include more cities and rural migrant households. However, we discovered migrant workers to be under-represented in the sample. Of the 388,459 workers observed in our sample between 2002-2007, slightly more than 1 percent $(4,456)$ were identified as migrant workers, a number that is much lower than reality.

To rectify this under-representation, we made an effort to estimate the size of the migrant workforce using alternative data sources. Some highly skilled migrant workers live in urban areas on a long-term basis and are able to meet the legal requirements of a "stable source of income" and "stable place of residence," which are necessary to obtain public services such as health care and schooling for their children. This type of migrant is likely to be included in the UHS sample. However, most rural migrant workers have few skills, and they compete with urban residents for low-income jobs. Many of these migrants live on the periphery of cities, residing in employer-provided dormitories or at their workplaces such as construction sites. Without a formal urban address, they have little chance of being covered by the UHS. Because of these factors, we estimate the size of the low-skilled rural migrant workforce and add these estimates to that of the low-skilled urban labor force.

The best data source for estimating the number of rural-to-urban migrants is the Chinese census. Since 2000, each individual covered in the census has reported his or her resident status. Hence, using the 2000 census and a 1 percent sample of the 2005 census, we estimate the size of the low-skilled rural migrant workforce. For the other years between 2000 and 2007, we estimate the size of this workforce by assuming a linear time trend over the time interval. We extrapolate migrant numbers between 1992 and 1999 by combining the estimates of Cai, Park and Zhao (2008) and our own estimates from the 2000 census. Finally, migrant workers are split into the state and the private sectors using the proportions observed in the 2002-2007 UHS data.

Exports: China's Ministry of Commerce has published export data by ownership category 
since 1994. For 1992 and 1993, we extrapolate exports in the state and private sectors using the estimated export/output ratio in the neighboring year. Total exports in US dollars in each sector are converted to 2007 yuan employing the annual exchange rates and CPI.

REDD Expenditure: Annual data on "expenses on science and research" since 1978 are collected from the SYC, and we employ them as a measure for domestic R\&D investment. Following the methods first proposed in Griliches (1979), we adopt the PIM to construct the stocks of domestic R\&D in 2007 prices. Following Hu, Jefferson and Qian (2005) and Fleisher and Zhou (2010), we assume the depreciation rates to be 15 percent.

FDI: Annual data on the "total amount of foreign capital actually utilized" since 1979 are drawn from the SYC. Again, we employ the PIM with a 15 percent depreciation rate to construct foreign capital stocks in 2007 price.

\section{SMM Estimation Procedure}

Let $m_{j}$ be moment $j$ in the data presented on the left-hand side of equations (12) to (14). The corresponding simulated moment is denoted by $m_{j}^{S}(\theta)$, which is obtained from 500 simulations, $m_{j}^{S}(\theta)=\frac{1}{500} \sum_{s=1}^{500} m_{j}^{s}(\theta) ; m_{j}^{s}(\theta)$ is computed as the right-hand side of equations (12) to (14). Our task amounts to finding a parameter vector $\theta$ that renders the modelsimulated base wage and wage premiums $\left(m_{j}^{S}(\theta)\right)$ as close as possible to the empirical ones $\left(m_{j}\right)$. The vector of moment conditions is

$$
g(\theta)^{\prime}=\left[m_{1}-m_{1}^{S}(\theta), \cdots, m_{j}-m_{j}^{S}(\theta), \cdots, m_{J}-m_{J}^{S}(\theta)\right],
$$

where $J=64$ is the number of moments used $(4$ moments $\times 16$ years $)$. We minimize the following objective function with respect to $\theta$

$$
L(\theta)=g(\theta)^{\prime} W g(\theta)
$$

where $W$ is a weighting matrix.

Following Lee and Wolpin (2010), we make two assumptions in forming the weighting matrix $W$ : (1) $W$ is diagonal and (2) $E\left[g_{j}(\theta)^{2}\right]=\sigma_{j}^{2} / N_{j}$, where $N_{j}$ is the number of individuals that comprise the $j$ th moment. We employ a two-step procedure to compute the diagonal elements of $W$. First, we set $\sigma_{j}^{2}=1$ and weight each sample moment by $N_{j}$. We estimate $\theta$ by minimizing (18) and allow $\widehat{\theta}$ to be the first-stage estimate of $\theta$. Second, we update

$\sigma_{j}^{2}$ according to $\sigma_{j}^{2}=E\left[g_{j}(\widehat{\theta})^{2}\right]$. Then, we weight each moment $j$ by $N_{j} / \sigma_{j}^{2}$ and estimate $\theta$ according to (18).

In each step, the solution to the aggregate labor market model is used as the inputs of 
the estimation procedure. The detailed procedure is as follows.

1. Make an initial guess for the parameter vector $\theta=\left\{\sigma_{j}, \rho_{j}, \lambda_{j}, \mu_{j}, \psi_{0}^{l}, \psi_{0}^{h s}, \psi_{0}^{c}, \gamma^{l}, \gamma^{h s}, \gamma^{c}, \eta_{\omega}\right\}$.

2. Randomly draw shocks to labor efficiency $\omega_{t}^{\prime} s$ from the normal distribution $N\left(0, \eta_{\omega}^{2}\right)$.

3. Use equation (11) and the observed number of workers at each educational level to calculate total labor efficiency units of each type. The observed employment of middle school workers in the state sector is adopted as the government employment restriction of low-skilled labor, $\overline{n_{t}^{l}}$. Compute equilibrium high-skilled labor allocation, $N_{s t}^{h}$, using equation (7).

4. Compute the neutral technology efficiency in both sectors, $A_{s t}$ and $A_{p t}$, using the production function specified in (5).

5. Simulate the wages of all labor types and compute the base wage and wage premiums in each year.

6. Run 500 simulations by repeating steps $2-5$, and then take their average to construct simulated moments, $m_{j}^{S}(\theta)$.

7. Compute the objective function $L(\theta)$.

8. Adjust the parameters and repeat steps 2-5 until the optimum is reached.

The variance-covariance matrix of the parameter estimates is given by $\left(A^{\prime} W A\right)^{-1}$, where $A$ is the matrix of the derivatives of the moments with respect to the parameters and $W$ is the inverse of the variance-covariance matrix of the moments. 


\section{References}

Autor, David H., Lawrence F. Katz, and Alan B. Krueger, "Computing Inequality: Have Computers Changed the Labor Market?" Quarterly Journal of Economics, 113 (1998), 11691213.

Bai, Chong-En, Chang-Tai Hsieh, and Yingyi Qian, "The Return to Capital in China," Brookings Papers on Economic Activity, 37 (2006), 61-88.

Barrell, Ray, and Nigel Pain, "Foreign Direct Investment, Technological Change, and Economic Growth within Europe," Economic Journal, 107 (1997), 1770-1786.

Bound, John, and George Johnson, "Changes in the Structure of Wages in the 1980's: An Evaluation of Alternative Explanations," American Economic Review, 82 (1992), 371-392.

Brandt, Loren, Trevor Tombe, and Xiaodong Zhu, "Factor Market Distortions Across Time, Space and Sectors in China," Working paper, 2011.

Cai, Fang, Albert Park, and Yaohui Zhao, "The Chinese Labor Market in the Reform Era," in China's Great Economic Transformation, Loren Brandt and Thomas Rawski, eds., 167-214 (Cambridge, UK: Cambridge University Press, 2008).

Caselli, Francesco, and Wilbur J. Coleman, "The U.S. Technology Frontier," American Economic Review, 92 (2002), 148-152.

Chan, Kam W., and Li Zhang, "The Hukou System and Rural-Urban Migration in China: Processes and Changes," The China Quarterly, 160 (1999), 818-855.

DiNardo, John, Nicole M. Fortin, and Thomas Lemieux, "Labor Market Institutions and the Distribution of Wages, 1973-1992: A Semiparametric Approach," Econometrica, 64 (1996), 1001-1044.

Dong, Xiao-Yuan, and Louis Putterman, "Soft Budget Constraints, Social Burdens, and Labor Redundancy in China's State Industry," Journal of Comparative Economics, 31 (2003), 110-133.

Duffy, John, Chris Papageorgiou, and Fidel Perez-Sebastian, "Capital-Skill Complementarity? Evidence From A Panel of Countries," Review of Economics and Statistics, 86 (2004), $327-344$.

Fallon, P. R., and P. R. G. Layard, "Capital-Skill Complementarity, Income Distribution, and Output Accounting," Journal of Political Economy, 83 (1975), 279-302.

Feenstra, Robert C., and Gordon H. Hanson, "Foreign Direct Investment and Relative Wages: Evidence from Mexico's Maquiladoras," Journal of International Economics, 42 (1997), 371393. 
Fields, Gary S., "Changing Labor Market Conditions and Economic Development in Hong Kong, the Republic of Korea, Singapore, and Taiwan, China," World Bank Economic Review, 8 (1994), 395-414.

Fleisher, Belton, and Mi Zhou, "Are Patent Laws Harmful to Developing Countries? Evidence from China," Ohio State University Working Paper, 2010.

Freeman, Richard B., and Lawrence F. Katz, "Rising Wage Inequality: the United States vs. Other Advanced Countries," in Working under Different Rules, Richard B. Freeman, ed. (Russell Sage Foundation, New York, 1994).

Ge, Suqin, and Dennis T. Yang, "Labor Market Developments in China: A Neoclassical View," China Economic Review, 22 (2011), 611-625.

Giles, John, Albert Park, and Juwei Zhang, "What is China's True Unemployment Rate?" China Economic Review, 16 (2005), 149-170.

Goldberg, Pinelopi K., and Nina Pavcnik, "Distributional Effects of Globalization in Developing Countries," Journal of Economic Literature, 45 (2007), 39-82.

Goldin, Claudia, and Lawrence F. Katz, "The Origins of Technology-Skill Complementarity," Quarterly Journal of Economics, 113 (1998), 693-732.

Griliches, Zvi, "Issues in Assessing the Contribution of Research and Development to Productivity Growth," Bell Journal of Economics, 10 (1979), 92-116.

Gustafsson, Björn, and Shi Li, "Economic Transformation and the Gender Earnings Gap in Urban China," Journal of Population Economics, 13 (2000), 305-329.

Hamermesh, Daniel S., Labor Demand. (Princeton, NJ: Princeton University Press, 1993).

Heckman, James J., Lance Lochner, and Christopher Taber, "Explaining Rising Wage Inequality: Explorations with a Dynamic General Equilibrium Model of Labor Earnings with Heterogeneous Agents," Review of Economic Dynamics, 1 (1998), 1-58.

Hsieh, Chang-Tai, and Peter J. Klenow, "Misallocation and Manufacturing TFP in China and India," Quarterly Journal of Economics, 124 (2009), 1403-1448.

Hu, Albert G. Z., Gary H. Jefferson, and Jinchang Qian, "R\&D and Technology Transfer: Firm-Level Evidence from Chinese Industry," Review of Economics and Statistics, 87 (2005), $780-786$.

Juhn, Chinhui, Kevin M. Murphy, and Brooks Pierce, "Wage Inequality and the Rise in Returns to Skill," Journal of Political Economy, 101 (1993), 410-442. 
Katz, Lawrence F., and David H. Autor, "Changes in the Wage Structure and Earnings Inequality," in Handbook of Labor Economics Volume 3A, Orley C. Ashenfelter and David Card, eds., 1463-1555 (North-Holland, 1999).

Katz, Lawrence F., and Kevin M. Murphy, "Changes in Relative Wages, 1963-1987: Supply and Demand Factors," Quarterly Journal of Economics, 107 (1992), 35-78.

Kim, Dae-Il, and Robert H. Topel, "Labor Markets and Economic Growth: Lessons from Korea's Industrialization, 1970-1990," in Differences and Changes in Wage Structures, Richard B. Freeman and Lawrence F. Katz, eds., 227-264 (Chicago, IL: University of Chicago Press, 1995).

Knight, John, and Lina Song, "Increasing Urban Wage Inequality in China," Economics of Transition, 11 (2003), 597-619.

Knight, John, and Linda Yueh, "Job Mobility of Residents and Migrants in Urban China," Journal of Comparative Economics, 32 (2004), 637-660.

Koopman, Robert, Zhi Wang, and Shang-Jin Wei, "How Much of Chinese Exports is Really Made in China? Assessing Domestic Value-Added When Processing Trade is Pervasive," NBER working paper No. w14109, 2008.

Krusell, Per, Lee E. Ohanian, José-Víctor Ríos-Rull, and Giovanni L. Violante, "Capital-Skill Complementarity and Inequality: A Macroeconomic Analysis," Econometrica, 68 (2000), $1029-1053$.

Lee, Young, "Wages and Employment in China's SOEs, 1980-1994: Corporatization, Market Development, and Insider Forces," Journal of Comparative Economics, 27 (1999), 702-729.

Lee, Donghoon, and Kenneth I. Wolpin, "Accounting for Wage and Employment Changes in the U. S. from 1968-2000: A Dynamic Model of Labor Market Equilibrium," Journal of Econometrics, 156 (2010), 68-85.

Li, David D., "Changing Incentives of the Chinese Bureaucracy," American Economic Review, 88 (1998), 393-397.

Meng, Xin, and Michael P. Kidd, "Labor Market Reform and the Changing Structure of Wage Determination in China's State Sector during the 1980s," Journal of Comparative Economics, 25 (1997), 403-421.

Mulligan, Casey B., and Yona Rubinstein, "Selection, Investment, and Women's Relative Wages Over Time," Quarterly Journal of Economics, 123 (2008), 1061-1110.

NBS, National Bureau of Statistics of China (various years), China Statistical Yearbook. (Beijing, China: China Statistics Press). 
Reimers, Cordelia W., "Labor Market Discrimination against Hispanic and Black Men," Review of Economics and Statistics, 65 (1983), 570-579.

Song, Zheng, Kjetil Storesletten, and Fabrizio Zilibotti, "Growing Like China," American Economic Review, 101 (2011), 196-233.

Sun, Linlin, and Ruoen Ren, "Capital Input Measurement: A Survey," China Economic Quarterly, 2005, 823-842.

Wang, Shing-Yi, "State Misallocation and Housing Prices: Theory and Evidence from China," American Economic Review, 101 (2011), 2081-2107.

Wu, Fulong, "Changes in the Structure of Public Housing Provision in Urban China," Urban Studies, 33 (1996), 1601-1627.

Yue, Ximing, "Issues in China's Labor Statistics," Economic Research Journal, 2005, 46-56.

Zhang, Junsen, Yaohui Zhao, Albert Park, and Xiaoqing Song, "Economic Returns to Schooling in Urban China, 1988 to 2001," Journal of Comparative Economics, 33 (2005), 730-752.

Zhao, Yaohui, "Earnings Differentials between State and Non-State Enterprises in Urban China," Pacific Economic Review, 7 (2002), 181-197. 

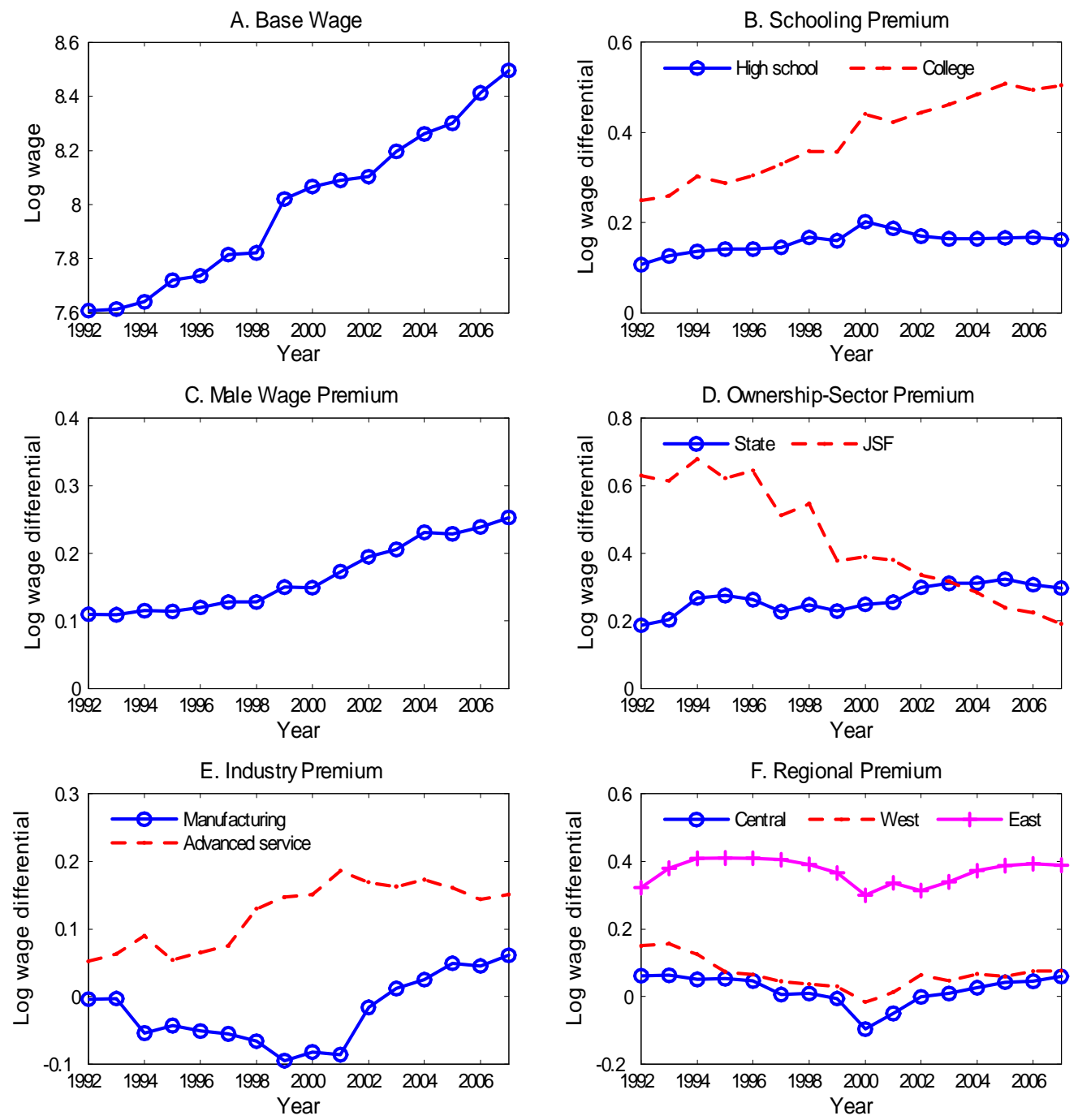

Figure 1: Changes in Conditional Mean Wages, 1992-2007 

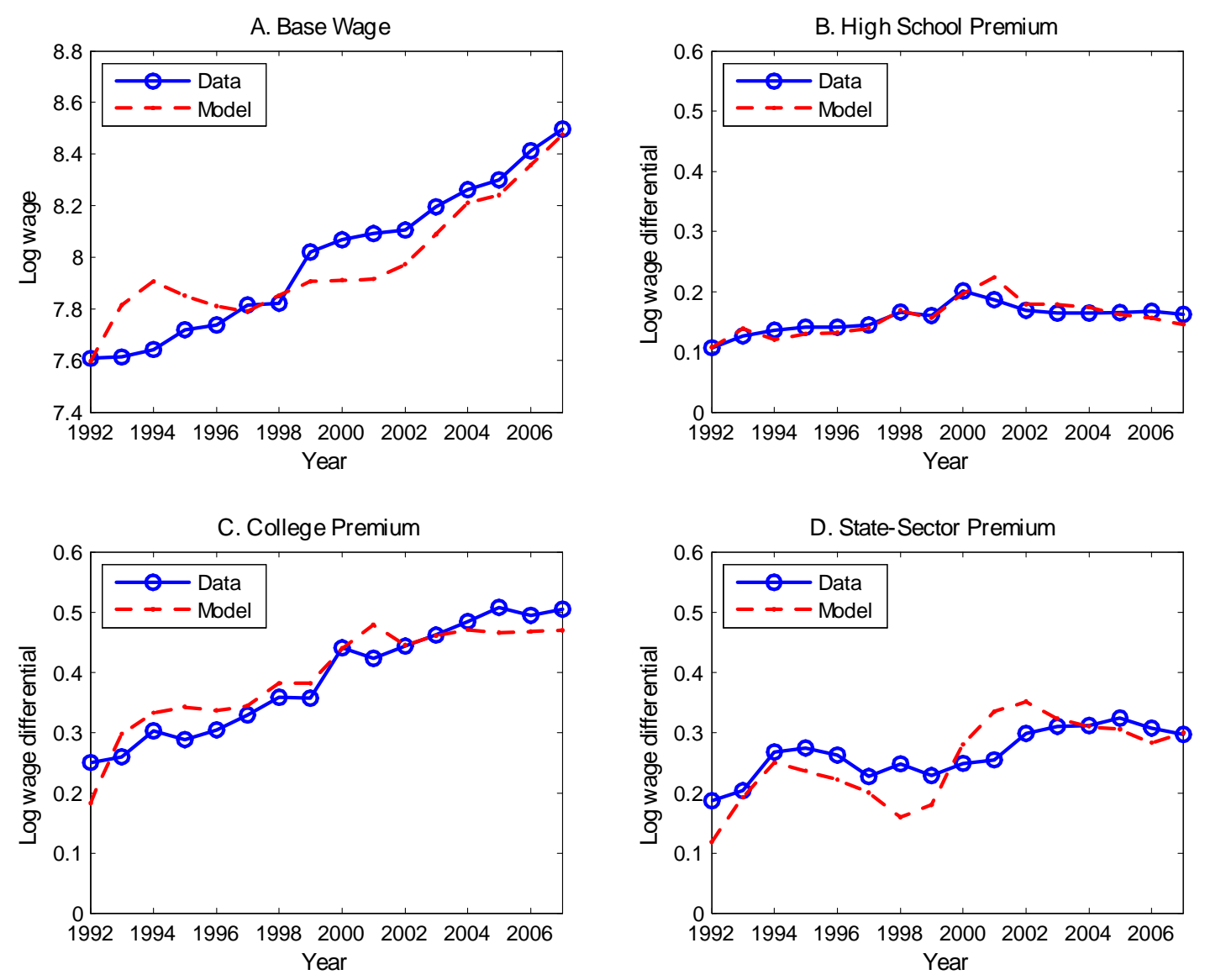

Figure 2: Actual and Predicted Base Wage and Wage Premiums, 1992-2007 
Table 1: Changes in Wage and Employment Structures in China, 1992-2007

\begin{tabular}{lcccccc}
\hline \hline & \multicolumn{2}{c}{ Wage level } & Wage growth & \multicolumn{2}{c}{$\begin{array}{c}\text { Employment } \\
\text { share }(\%)\end{array}$} & $\begin{array}{c}\text { Employment } \\
\text { change }(\%)\end{array}$ \\
\hline Classification of Group & 1992 & 2007 & $1992-2007$ & 1992 & 2007 & $1992-2007$ \\
\hline Whole sample & 6,193 & 18,695 & 201.9 & 100 & 100 & 100 \\
By education & & & & & & \\
$\quad$ Middle school and below & 5,764 & 13,547 & 135.0 & 41.9 & 25.7 & -16.2 \\
$\quad$ Vocational and high schools & 6,135 & 16,590 & 170.4 & 41.4 & 40.7 & -0.7 \\
College and university & 7,414 & 25,208 & 240.0 & 16.7 & 33.6 & 16.9 \\
By sex & & & & & & \\
Male & 6,754 & 21,111 & 212.6 & 50.2 & 53.9 & 3.7 \\
Female & 5,628 & 15,868 & 182.0 & 49.8 & 46.1 & -3.7 \\
By ownership & & & & & & \\
CIP & 5,067 & 14,096 & 178.2 & 28.5 & 43.7 & 15.2 \\
State & 6,550 & 23,565 & 259.8 & 69.7 & 32.6 & -37.1 \\
$\quad$ JSF & 10,291 & 20,501 & 99.2 & 1.8 & 23.7 & 21.9 \\
By industry & & & & & & \\
Manufacturing & 5,910 & 18,345 & 210.4 & 46.5 & 34.4 & -12.1 \\
$\quad$ Basic services & 5,950 & 15,368 & 158.3 & 24.9 & 39.1 & 14.2 \\
Advanced services & 6,864 & 24,076 & 250.8 & 28.6 & 26.5 & -2.1 \\
By region & & & & & & \\
Northeast & 4,993 & 14,027 & 180.9 & 16.6 & 12.1 & -4.6 \\
Central & 5,467 & 15,874 & 190.4 & 23.6 & 18.1 & -5.5 \\
West & 6,088 & 15,945 & 161.9 & 26.1 & 24.1 & -2.0 \\
East & 7,373 & 22,497 & 205.1 & 33.7 & 45.8 & 12.1 \\
\hline \hline
\end{tabular}


Table 2: Decomposition of Log Wage Differentials between 1992 and 2007

\begin{tabular}{lcc}
\hline \hline Sources of wage differential & $\begin{array}{c}\text { Change in log } \\
\text { wage }\end{array}$ & $\begin{array}{c}\text { Contribution to } \\
\text { total change (\%) }\end{array}$ \\
\hline Observed total change & 0.989 & 100.00 \\
Base wage & 0.372 & 37.58 \\
Due to factor returns and sector premiums & 0.554 & 55.96 \\
Schooling and experience & 0.352 & $(35.56)$ \\
Gender & 0.072 & $(7.26)$ \\
Ownership & 0.069 & $(7.00)$ \\
Industry & 0.058 & $(5.87)$ \\
Region & 0.003 & $(0.26)$ \\
Due to worker characteristics and reallocations & 0.064 & 6.46 \\
Schooling and experience & 0.091 & $(9.17)$ \\
Gender & 0.009 & $(0.91)$ \\
Ownership & -0.068 & $(-6.88)$ \\
Industry & -0.011 & $(-1.06)$ \\
Region & 0.043 & $(4.32)$ \\
\hline \hline
\end{tabular}

Table 3: SMM Estimates of Key Model Parameters, Benchmark and IV Specifications

\begin{tabular}{lcccc}
\hline \hline & \multicolumn{3}{c}{ Benchmark } & \multicolumn{3}{c}{ IV } \\
Parameters & Estimates & $(\mathrm{SE})$ & Estimates & $(\mathrm{SE})$ \\
\hline Curvature parameters & & & & \\
$\sigma_{s}$ & 0.596 & $(0.001)$ & 0.596 & $(0.001)$ \\
$\rho_{s}$ & 0.307 & $(0.009)$ & 0.307 & $(0.011)$ \\
$\sigma_{p}$ & 0.567 & $(0.002)$ & 0.565 & $(0.002)$ \\
$\rho_{p}$ & 0.338 & $(0.027)$ & 0.339 & $(0.030)$ \\
Effect of LATC on middle school workers & & & & \\
$\quad \gamma_{R \& D}^{l}$ & 0.006 & $(0.001)$ & 0.007 & $(0.001)$ \\
$\gamma_{F D I}^{l}$ & 0.016 & $(0.002)$ & 0.014 & $(0.003)$ \\
Effect of LATC on high school workers & & & & \\
$\gamma_{R \& D}^{h s}$ & 0.102 & $(0.036)$ & 0.102 & $(0.019)$ \\
$\gamma_{F D I}^{h s}$ & 0.127 & $(0.047)$ & 0.139 & $(0.029)$ \\
Effect of LATC on college workers & & & & \\
$\gamma_{R \& D}^{c}$ & 0.155 & $(0.055)$ & 0.173 & $(0.033)$ \\
$\gamma_{F D I}^{c}$ & 0.168 & $(0.062)$ & 0.171 & $(0.035)$ \\
\hline \hline
\end{tabular}


Table 4: Accounting for the Rise in the Base Wage and Wage Premiums

\begin{tabular}{|c|c|c|c|c|}
\hline & Base wage & $\begin{array}{c}\text { High school } \\
\text { premium }\end{array}$ & $\begin{array}{c}\text { College } \\
\text { premium } \\
\end{array}$ & $\begin{array}{c}\text { State } \\
\text { premium }\end{array}$ \\
\hline & $1992-2007$ & $1992-2007$ & $1992-2007$ & $1992-2007$ \\
\hline Log wage change in data & 0.888 & 0.055 & 0.255 & 0.111 \\
\hline \multicolumn{5}{|l|}{ Changes in } \\
\hline (1) Capital accumulation $(K)$ & 0.834 & 0.386 & 0.386 & -0.333 \\
\hline (2) $\operatorname{LATC}(X)$ & 0.659 & 0.038 & 0.287 & 0.016 \\
\hline (3) Supply of labor $\left(n^{l}, n^{h}\right)$ & 0.018 & -0.157 & -0.157 & -0.012 \\
\hline (4) SOE restructuring $\left(\overline{n^{l}}\right)$ & -0.206 & -0.225 & -0.225 & 0.610 \\
\hline (5) Residuals $(A)$ & -0.367 & 0 & 0 & -0.130 \\
\hline Benchmark with (1)-(5) & 0.878 & 0.038 & 0.287 & 0.182 \\
\hline
\end{tabular}

